\title{
Not All Silver Lining? The Great Recession and Road Traffic Accidents*
}

\author{
Paola Bertoli \\ University of Economics, Prague \\ CERGE-EI Teaching Fellow
}

\author{
Veronica Grembi \\ University of Milan \\ University of Economics, Prague
}

This draft: March 2018

\author{
Judit Vall Castello \\ Center for Research in Health and Economics (CRES) \\ Pompeu Fabra University
}

\begin{abstract}
We provide new evidence on the impact of recessions on traffic accidents by exploiting the case of Spain, where the effects of the 2008 economic crisis have been among the strongest in the developed world. We exploit differences in the incidence of the recession across Spanish provinces due to the unequal evolution of the real estate bubble across the country. We use a unique dataset on the universe of traffic accidents in Spain between 2004 and 2011. We first follow the literature on the topic and examine the impact of the economic crisis on the probability of having a traffic accident. However, we also go one step further, as we are able to identify any changes in the composition of both victims and driving behaviors as a result of the crisis. First, our results show that the Great Recession reduced traffic accidents in Spain. Second, regarding the compositional effects, we observe decreased probabilities of dying or reporting a serious injury. More important, we also detect an increase in the probability that people involved in an accident abused alcohol and drugs. Our results are robust to different measures of the crisis and the use of a spatial fixed effects model and are not biased by anticipatory effects. Finally, we show that our findings are driven by less-populated areas. Thus, we suggest that alcohol and drug control measures be reinforced during recessions and that more attention should be devoted to rural areas to strengthen the reduction in road traffic accidents.
\end{abstract}

*We are thankful for their comments on previous drafts of this work to two anonymous referees, Catia Nicodemo and the participants at the Second Workshop of Spatial Health Econometrics (University of York). We are thankful for their work as research assistants to Anna Barbeta Margarit and Nicolau Martin Bassols. The usual disclaimer applies. 


\section{Introduction}

There is a substantial literature on the short-run effects of economic crises on health outcomes. This paper contributes to this literature by exploiting the case study of Spain and focusing on what are defined as avoidable health costs: fatalities and injuries due to road traffic accidents. Recent works have revealed the existence of a casual relationship between the density of traffic and the incidence of traffic accidents (Romem and Shurtz 2016). Economic recessions are proven to reduce traffic density: more people are unemployed, and thus, their consumption habits change. Fewer need to drive to work, or they drive outside rush hours. This initially appears to be a positive spillover of economic crises. However, by the same token, the composition of accidents could change. For instance, an income effect might mean that shorter trips, for which the level of adopted precautions might be lower, could be favored over longer trips. Similarly, one might expect vehicle owners to perform less maintenance work due to income loss. This could increase the incidence of accidents or change the composition of the remaining accidents by, for example, increasing the likelihood of suffering a more severe accident. However, the opposite could also be true: one could decide to use a car only if it is in good condition because the monetary costs of an accident are now unaffordable. In addition, younger people, who are more affected by an employment crisis and are generally riskier drivers, are more likely to withdraw from the pool of potential drivers. By contrast, the set of older drivers, who might be less likely to have an accident, should be unchanged. Recent economic work has addressed the existence of this composition effect. Both Maheshri and Winston (2016) and Cotti and Tefft (2011) provide evidence from the US of an increase in the incidence of low-risk drivers when there is an economic crisis. These authors contend that this explains why fatality rates decrease more than accident rates.

Spain was among the European countries worst affected by the Great Recession of 2007/08. We rely on a unique dataset of the universe of traffic accidents that occurred in Spain between 2004 and 2011. For each accident, we have data on both the people and vehicles involved. We exploit the bursting of the real estate bubble in the country as a consequence of the crisis to identify the effects of the intensity of the Great Recession on the overall number of accidents. Furthermore, we also analyze any changes in the composition of the remaining pool of traffic accidents. Once the Great Recession struck, all Spanish provinces underwent an economic crisis. However, the real estate bubble affected certain provinces more than others. Assuming that provinces with more people involved in the construction sector suffered more from the Great Recession compared to those with fewer people involved in that sector (i.e., higher unemployment levels), we assess the effects of the intensity of the crisis on 
road traffic accidents. Our identification relies on the assumption that before the crisis, no major differences in the type of accidents exist between less construction oriented and more construction oriented provinces.

The richness of our dataset allows us to analyze not only the differences across provinces in terms of the accident rate but also to distinguish between the probability of death and the probability of suffering a severe or a minor injury (i.e., one that is not life treating). Moreover, we are also able to investigate in detail the composition effect, if any, of the accident set across provinces.

Our analysis proceeds in two steps. First, we evaluate the impact of the intensity of the economic crisis on the provincial-quarter rate of accidents, defined as the provincialquarter number of accidents per 1,000 provincial resident population. Then, we use the micro data from the universe of individual accidents to investigate the impact of the crisis on the composition of the remaining pool of traffic accidents. Specifically, we examine the severity of accidents, defined as the probability of dying and the probability of suffering a severe or a minor injury..$^{1}$ We focus on the link between the characteristics of an accident (e.g., the consumption of alcohol and drugs, or vehicle and weather conditions) and its severity. Second, we use these characteristics as outcomes of an independent analysis to investigate how they were affected by the crisis. We run this analysis on the overall sample of all Spanish provinces (50 here, as Ceuta and Melilla are excluded because they are two small provinces located outside Spain) and on a subsample excluding the 4 cities that contain more than 1,000,000 inhabitants (i.e., Madrid, Barcelona, Valencia, and Seville). This allows us to check whether the effect could be driven by the most urbanized areas.2 In addition, since these are the provinces most affected by commuting, dropping them also allows us to mitigate any potential bias due to commuting patterns.

Our results show that in provinces more affected by the Great Recession (i.e., the employment rate in the construction sector before the crisis was above the mean of the employment rate distribution), the overall accident rate decreases by $12 \%$ at the mean of the provincialquarter accident rate, and the rate of accidents on working days decreases by $14.7 \%$. With respect to the composition of traffic accidents, we report a decrease in the most severe accidents, observing a decline in the probability of dying or having a severe injury. However,

\footnotetext{
${ }^{1}$ According to the Spanish registry of accidents, a casualty is associated with a road traffic accident whenever a person dies within the 30 days after the accident. Deaths due to natural causes while driving (e.g., heart attack) and suicidal acts are excluded from this definition. Severe injuries are recorded whenever a person needs to be hospitalized for more than 24 hours as a result of an accident. If death occurred within 30 days after the accident, the case is not counted as a major injury. Minor injuries are recorded when a person needs to be hospitalized for 24 hours or less or does not require hospitalization.

${ }^{2}$ We are dropping the 4 corresponding provinces, which are easily identifiable with their main cities.
} 
the probability of suffering a minor injury increases. Back-of-the-envelope calculations, performed using the Value of a Statistical Life, provide an estimated savings on avoidable health expenditures due to road traffic deaths equal to 3 billion euros redistributed across Spanish provinces. The average age of people (and drivers) involved in an accident increases, due a decrease in the involvement of younger people and an increase in the involvement of older people. More important, people/drivers are more likely to be caught under the influence of alcohol. Furthermore, the average number of vehicles involved decreased, while the average number of people in a vehicle increased. Vehicles show fewer maintenance problems and are used for shorter trips, while accidents are less likely to occur during rush hours.

We perform a number of robustness checks both using alternative definitions of the treatment and testing different specifications of our baseline. As alternative proxies for the crisis, we use the employment rate in the construction sector at the provincial level as a continuous variable, rather than as a dummy, and the overall unemployment rate ${ }^{3}$ As an alternative specification of our baseline, we include weekday fixed effects, more detailed controls for weather conditions and/or a different clustering method for the standard errors. None of these robustness checks affect the validity of our results, which also hold in the less densely populated provinces (i.e., when dropping Madrid, Barcelona, Valencia and Sevilla). Finally, our findings at the provincial-quarter level are also robust to the use of a spatial panel fixed effects model.

These results are consistent with the large literature that reports positive health effects of economic recessions in the short run. Following the pioneering work by Rumh (2000), who shows that mortality decreased during downturns in the US, a number of additional papers have reported the same results for several other countries and for other health outcomes and health behaviors such as smoking, home-cooked meals or exercise. For the particular case of Spain, Tapia Granados (2005) shows that death rates increase during economic expansions and decrease during recessions (except for male suicides, which increase). The authors use data for the period 1980-1997, and thus, their results do not include the recent economic crisis. Other papers examining the impact of the 2008 recession in Spain focus on children's weight (Bells et al. 2016), drug consumption (Martin Bassols and Vall Castello, 2016) or self-assessed health and mental health (Urbanos-Garrido and Lopez-Valcarcel, 2015). The results of these recent papers are not as clear as those of previous years, and the pro-cyclical relationship reported in studies analyzing previous economic cycles may no longer hold for

\footnotetext{
${ }^{3}$ We also defined the treatment on the basis of the median of the distribution of the employment rate in the construction sector rather than the mean. We plot the trends in the accident rates of treated and controls according to this definition of treatment in Figure A1 of the Online Appendix. The results based on this treatment definition are available upon request.
} 
the latest economic crisis. Urbanos-Garrido and Lopez-Valcarcel (2015) find that both selfassessed health and mental health deteriorate (particularly for the long-term unemployed), while Bells et al. (2016) find reductions in children's obesity rates but also increases in the probability of being underweight for young children (aged 2 to 6). Finally, Martin Bassols and Vall Castello (2016) report increases in the consumption of marijuana and cocaine as a result of the 2008 economic crisis, in addition to a reduction in regular alcohol consumption and increases in the probability of smoking on a daily basis. Overall, the effects of the recent crisis in terms of health outcomes are more mixed than what has been reported for previous business cycle fluctuations in Spain. In a recent contribution, Ruhm (2015) pursues a similar line of investigation with respect to the US experience and also reports a shift in total mortality rates from being pro-cyclical to being unrelated to macroeconomic conditions. Ruhm also shows that, for the US, transport accidents continue to behave in a pro-cyclical manner even during the 2008 recession, following Miller et al. (2009), who show that the initial studies by Rumh are driven primarily by the decrease in road traffic fatality rates during recessions.

Thanks to the richness of our dataset, our results go one step further than the current literature on the avoidable health costs of road traffic accidents. We believe that our results are important to understand not only the target groups associated with fatality rates but also injuries on roads. Additionally, our findings show that less densely populated areas, where the use of private transportation is higher and more frequent, deserve special consideration when targeting a reduction in road traffic accidents, especially during bad economic times. Finally, we also draw attention to the increase in alcohol consumption by drivers as a result of the economic crisis. This last finding suggests that alcohol controls should be reinforced during recessions to maximize the benefits of reduced accident rates.

\section{Background and Data}

The economic crisis that began in 2008 affected many countries around the world. However, in Spain, the recession had some distinct features: it was affected by both the global financial crisis and a construction bubble. The global financial crisis caused gross domestic product (GDP) to contract, which was accompanied by reduced capital investment and domestic demand. As Figure 1 shows, GDP growth in Spain posted negative numbers in 2008 for the first time in 15 years. At the height of the recession, Spains GDP declined by more than at any other time since the contraction following the Civil War. The decline in GDP growth began at the beginning of 2008, going from 3.5\% in the fourth quarter of 2007 to $2.9 \%$ in the 
first quarter of 2008. In the fourth quarter of 2008 GDP growth reached negative numbers $(-1.25 \%)$. There was a mild recovery in the last three quarters of 2010 (with small positive GDP growth), but in the first quarter of 2011, GDP growth turned negative again until 2014 (see Figure 1).

Figure 1 about here

Simultaneously, Spain faced a construction crisis with the bursting of the so-called Spanish real estate bubble $4^{4}$ During the first half of the 2000s, rising housing prices in Spain led to the mass construction of new buildings. The Bank of Spain estimates that housing prices rose 100\% in real terms between 1997 and 2006 (which is the equivalent of $150 \%$ in nominal prices), and 5 million new houses were built between 2000 and 2009. Between 1997 and 2006 , the construction sector's contribution to total value added increased by $15 \%$ in the USA, 28\% in the UK and 67\% in Spain (Aparicio, 2014). As a result of this rapid growth, according to data from the Bank of Spain, investment in construction in Spain accounted for $22 \%$ of GDP in 2007 (Banco de Espana, 2012). The booming economy entailed very low levels of unemployment (below 10\%), which is unusual for Spain. However, coinciding with the global economic crisis and the bursting of the construction bubble, unemployment rates increased dramatically from 2008 until 2013, when they began to decrease. At its peak, the unemployment rate reached $27 \%$ in the first trimester of 2013. Although it has continuously decreased since then, the unemployment rate still stood at $18.6 \%$ in 2016 . Figure 2 shows the overall trend of unemployment between 2002 and 2016. An important part of the increase in unemployment was led by the collapse of the construction sector in Spain. To illustrate this, Figure 3 plots the composition of unemployment in Spain according to each sector of activity (agriculture, industry, construction, services and those without previous employment) from 2001 to 2012. We constructed this Figure using data from the Spanish Public Employment Service (Servicio Publico de Empleo Estatal). In the Figure we can see that a very important share of the increase in unemployment that occurred from 2008 onward occurred in the construction sector.

This second element of the economic crisis, the construction bubble, was concentrated in specific areas of Spain. Therefore, the crisis was unevenly felt across the country. The local economies of a number of Spanish regions were based on the construction sector, but others relied on different sectors such as services or manufacturing. As a result, when the

\footnotetext{
${ }^{4}$ Spain was not the only country to suffer a construction bubble, but the intensity of this bubble in Spain was generally stronger than in other countries. For example, between 2001 and 2008 in the United States, one new house was constructed for every 23.5 citizens. In Spain, one new house was constructed for every 9.2 citizens during the same period.
} 
bubble burst, some regions felt the impacts more strongly, and regional unemployment rates responded accordingly. Therefore, unemployment rates varied substantially across Spanish provinces, with some regions experiencing strong increases in unemployment, while in others it remained relatively low, as shown in Figure 4. Panel (a). In Panel (b), we plot the differences across provinces in the employment growth rate for the construction sector. In Panel (a), the darker areas identify those provinces where the unemployment rate increased the most, while in Panel (b), the darker shading identifies provinces where employment in the construction sector decreased the most. From Figure 4, it is apparent that there is a strong geographical correlation between provinces where unemployment increased and those where employment in the construction sector decreased. As a consequence, we exploit the different rates of employment in the construction sector in 2007 as a predictor of the intensity with which the crisis was experienced at the provincial level from 2008.

Figures 2, 3, and 4 about here

We use register data from the universe of traffic accidents in Spain between 2004 and 2011 from the Spanish General Traffic Directorate. For each accident, we have detailed information on the characteristics of the accident, the persons and vehicles involved and the type of road where it took place. As a result, we can exploit three datasets: one at the accident level, one at the vehicle level, and one at the individual level. Overall, during our observational period, 730,606 road traffic accidents occurred involving 1,278,248 vehicles and 1,752,029 individuals. Table 1 shows the main descriptive statistics. At the provincial-quarter level, there are 0.48 accidents per 1,000 inhabitants, which is not dramatically different from the value for the sample that excludes Madrid, Barcelona, Valencia, and Seville. The accident rate during workdays declines to 0.25 and 0.24 in the two samples. On average, $1 \%$ of the people involved in a road traffic accident die, $8 \%$ report a serious injury, and nearly $52 \%$ report minor injuries. The average age of a person involved is approximately 37 , with $17 \%$ of the people being older than 60 . Additionally, $2 \%$ of the people were under the influence of alcohol, and over $60 \%$ were taking some form of precaution while in the vehicle. Rush hours accounted for $53 \%$ of accidents; more than $86 \%$ were experienced during good weather conditions and while driving on dry and clean streets.

Table 1 and Figure 5 about here

Finally, for consistency with Figure 4, Figure 5 shows the rate of growth in both the accident rate and the weekday accident rate at the provincial level. We built the growth rate using the average accident rate per province for the period before and after the crisis. 
It appears that areas that suffered from a decrease in employment in the construction sector are also those where the accident rates decreased the most.

\section{Empirical Strategy}

When the Great Recession began, some provinces faced higher unemployment than others; thus, our empirical analysis identifies the effect of an increase in the intensity of unemployment. Since employment in the construction sector and the growth rate of unemployment are highly correlated, as shown in Section 2, we pay particular attention to the interaction effect of having an accident in a province that registered an above-mean employment level in the construction sector in the first quarter of 2007 (treated group) compared to having an accident in a province with a below-mean level of employment in the construction sector in the first quarter of 2007 (control group) before and after the beginning of the recession in 2008. We use the first quarter of 2007, as this coincides with the peak of the real estate bubble. Thus, we use the distribution of the employment rate in this quarter to define treated and control.

Define Accidents $_{p q}$ as the accidents collapsed at the provincial-quarter-year level and normalized to thousands of provincial residents, while Severity $y_{i p t}$ defines one of three dummy variables: Death, which is equal to 1 if the person involved in the accident died, Severe Injury, which is equal to 1 if the person involved in the accident reported a major injury, and Minor Injury, which is equal to 1 if the person involved in the accident reported a minor injury. Our analysis is based on the estimation of the following models:

$$
\text { Accidents }_{p q}=\delta \text { Crisis }_{p q}+\gamma_{q}+\alpha_{p}+\epsilon_{p}
$$

$\delta$ is the coefficient of interest, where Crisis $=$ Treated $_{p} *{\text { Post } 08_{q}}_{\text {. Treated is equal to } 1}$ if province $p$ had an employment rate in the construction sector above the mean in the first quarter of 2007 and 0 otherwise. Post08 is a dummy equal to 1 for the period after the first quarter $q$ of 2008, 0 otherwise. $\gamma_{q}$ are the quarter-year fixed effects to control for common shocks and seasonality effects; $\alpha_{p}$ are provincial fixed effects to control for unobservable timeinvariant characteristics at the provincial level, such as driving habits. Standard errors are clustered at the provincial level for the model in Equation 1 and at the provincial-quarter level for the model in Equation 2 to address serial correlation problems.

In this setup, we need to address two major concerns. First, as a consequence of the crisis, 
the resident population in each province could change, as people could emigrate in search of a job from more- to less-affected provinces. This could affect our outcome variables. Accidents $_{p q}$ could increase or decrease, not because there is a direct change in the number of accidents, but because the denominator varies. In addition, people who decide to move could be also the most skilled, and this could affect the probability of having a more- or less-severe type of injury. Obviously, if this is the scenario in place, this would be the effect of the crisis but through a different, indirect channel. Finally, the crisis could have triggered migration among the younger population - or the population most able to work - with consequences for the composition effect. Second, we need to show that before the crisis took place, the trends in accident rates were common across treated and control provinces.

Figure 6 shows the parallel trends in the resident populations in treated and control provinces, overall and as percentages of residents younger than 30 and between 30 and 60, while Figure 7 shows the trends in accident rates. It is apparent that treated and control provinces do have common trends before the crisis struck in 2008, when the decrease in the accident rates is higher in treated than in control provinces. In addition, this analysis does not reveal any change in the resident population figures as a consequence of the crisis, and the percentages of younger residents display common trends across treated and control provinces. Panel (c) of Figure 6 reveals the convergence of the trends in the percentage of the population between 30 and 60 between treated and control provinces after the crisis. However, this range of population increases for the treated, meaning that we should expect an increase in accidents involving this segment of the population if our results are driven by a pure migration effect.

Figures 6 and 7 , about here

Once we estimate Equation 1, we focus our analysis on exploring any changes in the composition of the traffic accident pool as a result of the onset of the Great Recession. Thus, we analyze changes in the severity of accidents and any changes in behaviors (individual level), skills (individual level) or conditions (accident level) on the remaining traffic accidents. We estimate the model described by Equation 2, which adds a series of controls, at both the people and accident levels, grouped in the vector $X 1_{i p t}^{\prime} ._{5}^{5}$ For the analysis at the individual level, we consider as controls the use of alcohol, age, being stressed or tired, the adoption of precautions while driving, the type of driving experience, and whether the vehicles involved had any maintenance problems. For the analysis at the accident level, we include as controls

\footnotetext{
${ }^{5} i$ indicates the individual level. When we analyze the accident level, we replace $i$ with $a$, which represents characteristics at the accident level.
} 
the role played by weather and road conditions, as well as the occurrence of more severe accidents on certain days or at certain hours. ${ }^{6}$

$$
\begin{gathered}
\text { Severity }_{i p t}=\delta \text { Crisis }_{p q}+X 1_{i p t}^{\prime}+\gamma_{q}+\alpha_{p}+\epsilon_{p t} \\
X 1_{i p t}=\delta \text { Crisis }_{p q}+\gamma_{q}+\alpha_{p}+\epsilon_{p t}
\end{gathered}
$$

Finally, we examine how the differences in the intensity of the crisis affect the controls grouped in $X 1_{i p t}^{\prime}\left(\right.$ and $\left.X 1_{\text {apt }}^{\prime}\right)$ when estimating Equation 3 . This step allows us to detect how the crisis affected the composition of the people involved in a road traffic accident and the accident types. In doing so, we estimate the models on the dataset that includes all provinces and on a subsample from which we drop the four largest cities in Spain (i.e., those with above 1 million residents): Madrid, Barcelona, Valencia, and Seville. We do this for several reasons: first, we want to rule out the possibility that our effects are driven solely by these four metropolitan cities. Second, we want to explore the existence of any systematic differences in terms of accident composition in more densely populated versus rural areas. Third, we want to attenuate concerns related to the fact that those areas will receive more commuters from nearby provinces, meaning that some of the accidents occurring in these largest provinces may involve individuals not living in them.7 The importance of these distinctions is confirmed by a heterogeneity analysis performed at the provincial-quarter level by exploiting three types of provincial-level information: infrastructure investments, population density, and the number of registered vehicles. To assess whether the responses to the crisis differed, conditional on the magnitude of one of these three measures, we estimate the model in Equation 1 while adding a dummy $D$ equal to 1 if one of these variables is above the mean of its distribution for a province $p$ in year 2007 (before the crisis) and zero otherwise.

\footnotetext{
${ }^{6}$ According to descriptive evidence, more severe accidents tend to occur during the weekend and in apparently good driving conditions; see Bertoli and Grembi (2017).

${ }^{7}$ To provide an idea of the importance of commuters, we use the 2007 Spanish Labor Force Survey to calculate the percentage of individuals in each province that commute to another province for work. We calculated that in $77 \%$ of the provinces in Spain, the number of commuters was lower than $6 \%$. Only in three provinces (out of the 50 provinces in Spain) was the number of commuters higher than $10 \%$ (10.62\% in Avila, $14.68 \%$ in Guadalajara and $11.23 \%$ in Toledo), and these provinces neighbor Madrid. Therefore, we believe that these are relatively small numbers of commuters that will not lead to important biases. Finally, due to the inclusion of provincial fixed effects in all regressions, if commuting behavior remains stable over time, then any commuter effect should be absorbed by the fixed effects.
} 
We interact $D$ with Crisis to assess whether provinces with a higher/lower value of each of these measures reacted differently. As shown in Table A2 in the Online Appendix, the effect on accident rates is driven primarily by less densely populated areas.

\section{Results}

In the provinces more affected by the economic crisis, the accident rate decreased by $12 \%$ at the mean of the variable, while there is a stronger decrease (of 14.7\%) in the accident rate during workdays, as shown in Table 2. Figure 8 plots the coefficients of the leads and lags for the quarters before and after the effect of the economic crisis to check for any anticipatory effect. We do not find any significant difference in the accident rate between the treatment and control group in the period before the onset of the economic crisis. Furthermore, we observe a significant decline in the accident rate from the first quarter of the economic crisis.

Table 2 and Figure 8 , about here

We recognize that in the present setup, the accident rates of neighboring provinces may show a certain degree of correlation. Provinces are of a relatively small size, and individuals clearly move across them to work, go shopping, participate in leisure activities, and so forth. As a consequence, it is reasonable to expect that the accident rate in a province may also be affected by how much the neighboring provinces are suffering from the crisis. To control for these potential effects, we move from Equation 1 and estimate a spatial panel fixed effects model that allows us to account for both spatial lag and spatial error correlation (Anselin, 1998) 8 The spatial model confirms both the magnitude and sign of the effects of the full baseline regression (Table 22). In addition, it also supports the expected positive correlation between the accident rates of neighboring provinces: high accident rates in neighboring provinces are associated with higher rates in the province under consideration. Thus, this provides additional evidence on the robustness of the results while adding additional insights into the spillover effects across neighboring provinces.

\footnotetext{
${ }^{8}$ Equation 1 is changed as follows:

$$
\begin{gathered}
\text { Accidents }_{p q}=\rho W \text { Accident }_{p q}+\delta \text { Crisis }_{p q}+\gamma_{q}+\alpha_{p}+\epsilon_{p q} \\
\epsilon_{p q}=\lambda E \epsilon_{p q}+u_{p q}
\end{gathered}
$$
}

where $W$ is the spatial matrix for the spatially lagged dependent variable, $E$ the spatial matrix for the error term, $\rho$ the spatial autoregressive coefficient, and $\lambda$ the spatial autocorrelation parameter. We consider a row-standardized weighting matrix computed using the Euclidean distances between the centroids of the provinces. 
If we turn to the analysis to the compositional effects and focus on the severity of accidents, Table 3 shows that the probability of dying (for the analysis at the individual level) in an accident decreases by $21.4 \%$ at the mean of Death, while the probability of reporting a severe injury decreases by $21 \%$ at the mean of SevereInjury. Interestingly, the probability of reporting a minor injury increases as a consequence of the crisis, by $2.5 \%$. In the subsample of provinces that excludes the large cities, the direction of the effect is confirmed while the magnitude of the impact changes slightly: the probability of dying declines by $15.8 \%$, that of a major injury declines by $16.3 \%$, and that of reporting a minor injury increases by $3.5 \%$.

We now briefly analyze the determinants of each of the severity levels of an accident in an attempt to shed some light on the potential explanations driving the changes in the probability of having each type of accident due to the economic crisis. By examining Table 3. we can assess how different behaviors and characteristics affect the different degrees of accident severity. For instance, the consumption of alcohol and drugs negatively affects the probability of dying or reporting a major injury but positively affects the probability of reporting a minor injury. New vehicles are more likely to be involved in cases of deaths or severe injuries than in cases of minor injuries. However, if the vehicle has any maintenance problems, this increases the severity of an accident under all three dimensions of severity, as does having few years of driving experience. In general, short trips are more associated with less-severe outcomes. The results do not change substantially when moving to the sample without the four large cities, which reinforces the idea that these are common patterns across both more- and less-populated regions. Both the direction and the magnitude of the effect of the economic crisis are confirmed by the analysis using the accident-level dataset. Table 4 shows the results. 9 The number of deaths per accident decreased by $21 \%$ (or 0.7 fewer deaths per 100 accidents $-0.007^{*} 100$ ) at the mean of the variable, while the number of seriously injured individuals decreased by $21 \%$, and the number of minor injured people increased by $1.7 \%$. In the sample without the four large cities, the corresponding values are $-17.4 \%,-18.6 \%$, and $+2.7 \%$. The most severe accidents (i.e., more deaths and more severely injured) take place not on workdays or during rush hours but rather during weekends. In addition, they generally involve fewer vehicles and clean streets, and have a lower probability of occurring during good weather conditions.

Tables 3 and 4 about here

Tables 5 and 6 report the impact of the economic crisis on the main characteristics and behaviors of people involved in traffic accidents. To provide a better picture of the

\footnotetext{
${ }^{9}$ This means that we are not estimating the effect on the probability of dying, for instance, but on the number of deaths at the accident level.
} 
composition effect, we split the variable Age using three dummies, one for people less than 30 years old, one for those aged from 30 to 60 years, and one for people older than 60 . We also distinguish between all individuals involved in an accident versus only considering the drivers of the vehicles involved. Overall, the average age at which individuals have an accident increases during the economic crisis. From the pool of injured individuals, those more likely to be employed (i.e., younger people) are being replaced by those older than 60 years. Similarly, the incidence of people acting under the influence of drugs and alcohol also increases. In terms of the composition of the pool of people involved in accidents, more had driving experience, while there is no difference in gender, nationality, the tendency to report being tired or stressed when the accident occurred or in their use of precautions (Table 5 . Panels A-B-C). Considering drivers in isolation, we see that they tend to have more driving experience, be Spanish, have abused drugs and alcohol, and be older (Table 5 , Panels D-E-F). Again, there is a change in the composition of the age groups (with a lower incidence among the younger and higher incidence among the 60-plus group).

Overall, there were fewer maintenance problems reported but also fewer new vehicles involved (Table 6). Nevertheless, the number of people in the vehicles increased, and pedestrians were more likely to be involved (Panels A and B). Finally, as shown in Panels C, D, and E, fewer accidents were recorded during rush hours or workdays. Regarding the length of the trip, short trips slightly increased.

These results are consistent with the idea that, due to the substantial job losses triggered by the recession, there is a strong reduction in the number of people using their vehicle to go to work, and thus, the accidents associated with job-related commuters are disappearing from the pool of accidents (e.g., fewer accidents for working-age individuals, during rush hours and on workdays). However, we also detect an increase in the number of accidents due to alcohol- and drug-related problems in the pool of traffic accidents. This is consistent with the reduction in the severity of accidents during the economic crisis, as alcohol consumption is associated with milder accidents (as seen in Table 3). In any case, the increase in alcoholand drug- related accidents during recessions stands as an important finding, as it prevents further reductions in the overall accident rate during bad economic times.

Tables 5 and 6, about here

The picture we obtain from the same analysis on the subsample of provinces that excludes the four large cities presents some small differences, as reported in Tables 7 and 8 . Some results are the same as in the overall sample. For example, age increases throughout Spanish territory (Panels A and D in Table7), and the probability of drivers having consumed drugs 
and alcohol when involved in an accident increases (Panels B and E). The main differences in the sample without the large cities are that there is a decrease in the likelihood of reporting being stressed and tired and an increase in the adoption of precautions (Panels B-C and EF). Finally, the economic crisis does not change the probability of having an accident during rush hours or on workdays when we restrict the sample to exclude the four large cities, as we reported for the overall sample. Thus, it appears that the employment destruction channel is more important in explaining the reduction in the total number of accidents in large cities than in the rest of the less-densely populated territory. A further minor difference with the analysis of the full sample is a decrease in the probability of having an accident during good weather conditions and on dry and clean roads (Table 8, Panel D). Thus, it appears that the decision of when (under what conditions) to drive was most affected in this sample.

Tables 7 and 8, about here

\section{$5 \quad$ Robustness checks}

We test our baseline results on the severity of accidents, at both the individual and accident levels, using alternative definitions of the treatment. First, we retain our initial measure (i.e., the employment level in the construction sector), but we do not use a dummy based on the mean of the distribution of the variable; instead, we use a continuous variable. Hence, the new treatment is the interaction between the level of employment in the construction

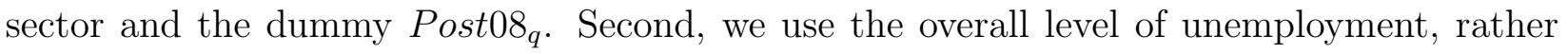
than focusing on the employment level in a specific sector. In this alternative scenario, the treatment is defined as the interaction between the level of unemployment and the dummy $\operatorname{Post}_{4}$. We test Equation 2 using these two types of treatment and we report the results in Table 9. The direction and the significance of the effect of the crisis is consistent with our baseline specification.

To test the robustness of our specification, we also refine some of our control variables. First, we use weekday fixed effects, rather than weekdays or the dummy for the weekend and our main results are confirmed as shown in Panels A and H of Table10. Second, our findings are robust also to the inclusion of more refined controls for weather conditions ${ }^{10}$ as reported in Panels B and I, as well as to that of both weekday fixed effects and the weather controls (Panels $\mathrm{C}$ and $\mathrm{J}$ ). Third, we use a two-way clustering by province and date, rather than the one-way clustering at the province-quarter-year, for the standard errors. This check allows

\footnotetext{
${ }^{10}$ Specifically, we replace the general control for good weather conditions with three dummies controlling for sunny days (Sunny), rainy days (Rain) and foggy days (Fog).
} 
us to take into account both time and the geographical serial correlations. Panels D and K of Table 10 show the results. Finally, we combine the two-way clustering with weekday fixed effects and weather controls in a stepwise manner, as shown in Panels E-G and L-N.

Tables 9 and 10 , about here

\section{Conclusions}

The literature has established that accident rates decrease when the economy deteriorates. However, less is known about the composition of accidents during bad economic times. We contribute to this literature by analyzing the response of accident rates to the 2008 Great Recession in Spain.

Our results show a $12 \%$ decrease in the accident rate at the mean of the variable in the provinces more affected by the crisis. This is combined with a decrease in the probabilities of dying and of suffering a major injury. To quantify the "savings" in terms of avoidable deathrelated expenditures, we compute some back-of-the-envelope calculations using the Value of a Statistical Life provided by the OECD (2012) and based on the average of 27 countries, which is equal to $4,131,970$ euros. Since our estimated coefficient on the probability of dying is 0.003 and the number of accidents in 2007 in Spain is equal to 242,957, these savings amount to $\left(0.003^{*} 242,957\right)=729^{*} 4,131,970=3,012,206,130$ euros distributed across the various provinces 11

In addition to this composition effect across accidents, our analysis also reveals a strong composition effect across the types of people involved in the accidents. People modify their behaviors, and there is a substitution across generations. Specifically, the incidence of people older than 60, as well as those acting under the influence of drugs and alcohol, increases. Finally, our findings are not driven by the most densely populated areas of the country.

From a policy perspective, these results offer relevant insights to better address traffic accidents during recessions. Our paper provides interesting information on how people change their driving behavior and habits when economic conditions deteriorate. Although the accident rate decreased as a result of the 2008 Great Recession, policy makers could further combat traffic accidents by targeting dangerous behaviors. Those behaviors are more likely to affect the most severe health outcomes of accidents. For example, more effort could be devoted to discouraging people from driving under the influence of alcohol and drugs. This

\footnotetext{
${ }^{11}$ We cannot provide a similar calculation for the avoided severe injuries, as we lack sufficient information on the average compensation paid per accident.
} 
could be done by simply reinforcing existing policies such as increasing the number of alcohol and drug tests on the roads. More interestingly, during bad economic times, efforts to prevent road traffic accidents should be intensified in rural areas, rather than in the most highly populated places. 


\section{References}

Abouk, R. and S. Adams (2013). Texting Bans and Fatal Accidents on Roadways: Do they Work? Or Do Drivers Just React to Announcements of Bans? American Journal of Economics: Applied Economics 5: 179-199.

Anderson, M. L., and M. Auffhammer (2014). Pounds That Kill: The External Costs of Vehicle Weight. Review of Economic Studies 81: 535-571.

Aparicio-Fenoll, A. (2016). Returns to Education and Educational Outcomes: The Case of the Spanish Housing Boom. Journal of Human Capital 10: 235-265.

Banco de Espana (2012). Challenges in the Euro Area. Documentos Ocasionales N1201, Banco de Espaa, Madrid.

Bassols, N. M., and J. Vall Castello (2016). Effects of the Great Recession on Drugs Consumption in Spain. Economics and Human Biology 22: 103-116.

Bells, C., Jimenez-Martin, S., and J. Vall Castello (2016). Bad times, slimmer children?. Health Economics 25(S2): 93-112.

Bertoli, P., and V. Grembi (2017). The Life-saving effect of hospital proximity, Health Economics, forthcoming.

Cotti, C., and N. Tefft (2011). Decomposing the Relationship between Macroeconomic Conditions and Fatal Car Crashes during the Great Recession: Alcohol and NonAlcohol-Related Accidents 11: art.48.

Edlin, A. S., and P. Karaca-Mandic (2006). The Accident Externality from Driving. Journal of Public Economics 114: 931-955.

Jacobsen, M. R. (2013). Fuel Economy and Safety: The Influences of Vehicle Class and Driver Behavior. American Journal of Economics: Applied Economics 5: 1-26.

Miller, D. L., Page, M. E., Stevens, A. H., and M. Filipski (2009). Why Are Recessions Good For Your Health? American Economic Review: Papers and Proceedings, 99: $122-127$.

Maheshri, V., and C. Winston (2016). Did the Great Recession Keep the Bad Drivers Off the Road? Journal of Risk and Uncertainty. Journal of Risk and Uncertainty, 52(3): $255-280$.

Martin-Bassols, N., and J. Vall Castello (2016). Effects of the Great Recession on drug consumption in Spain. Economics and Human Biology 22: 103-116.

Noland, R. B., and Y. Zhou (2017). Has the great recession and its aftermath reduced traffic fatalities? Accident Analysis and Prevention 98: 130-138. 
OECD (2012). Mortality Risk valuation in environment, health and transport policies. OECD publishing.

Romem, I., and I. Shurtz (2016). The Accident Externality of Driving: Evidence from Observance of the Jewish Sabbath in Israel. Journal of Urban Economics 96: 36-54.

Ruhm, C.J (2000). Are recessions good for your health? Quarterly Journal of Economics 115(2): 617-650.

Ruhm, C.J (2015). Recessions, healthy no more?. Journal of Health Economics 42: 17-28.

Tapia Granados, J (2005). Recessions and mortality in Spain, 1980-1997. European Journal of Population 21(4): 393-422.

Urbanos-Garrido, R.M., and B.G. Lopez-Valcarcel (2014). The influence of the economic crisis on the association between unemployment and health: an empirical analysis for Spain. European Journal of Health Economics 16(2): 175-84. 


\section{Tables and figures}

Figure 1: GDP Growth in Spain (1995-2016)

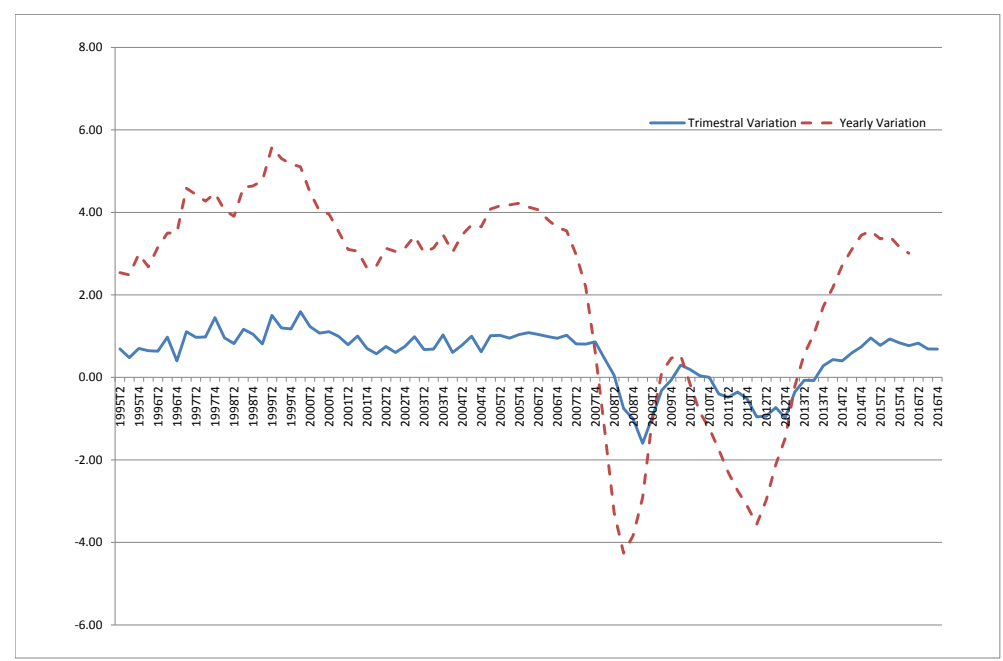

Source: Spanish Institute of Statistics. The dashed line represents the yearly variation, while the continuous line the quarterly variation.

Figure 2: Unemployment Rate in Spain (2002-2016)

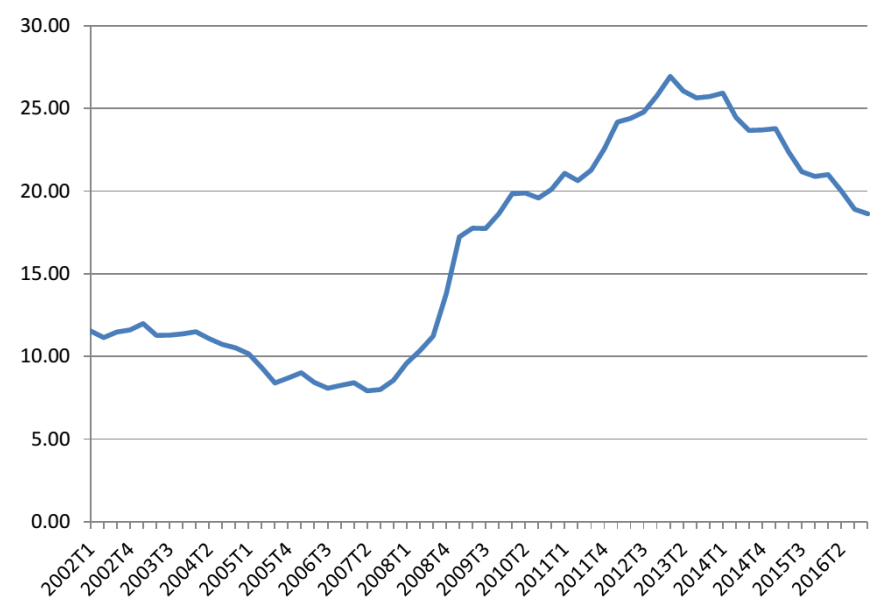

Source: Spanish Institute of Statistics. 
Figure 3: Unemployment By Sector

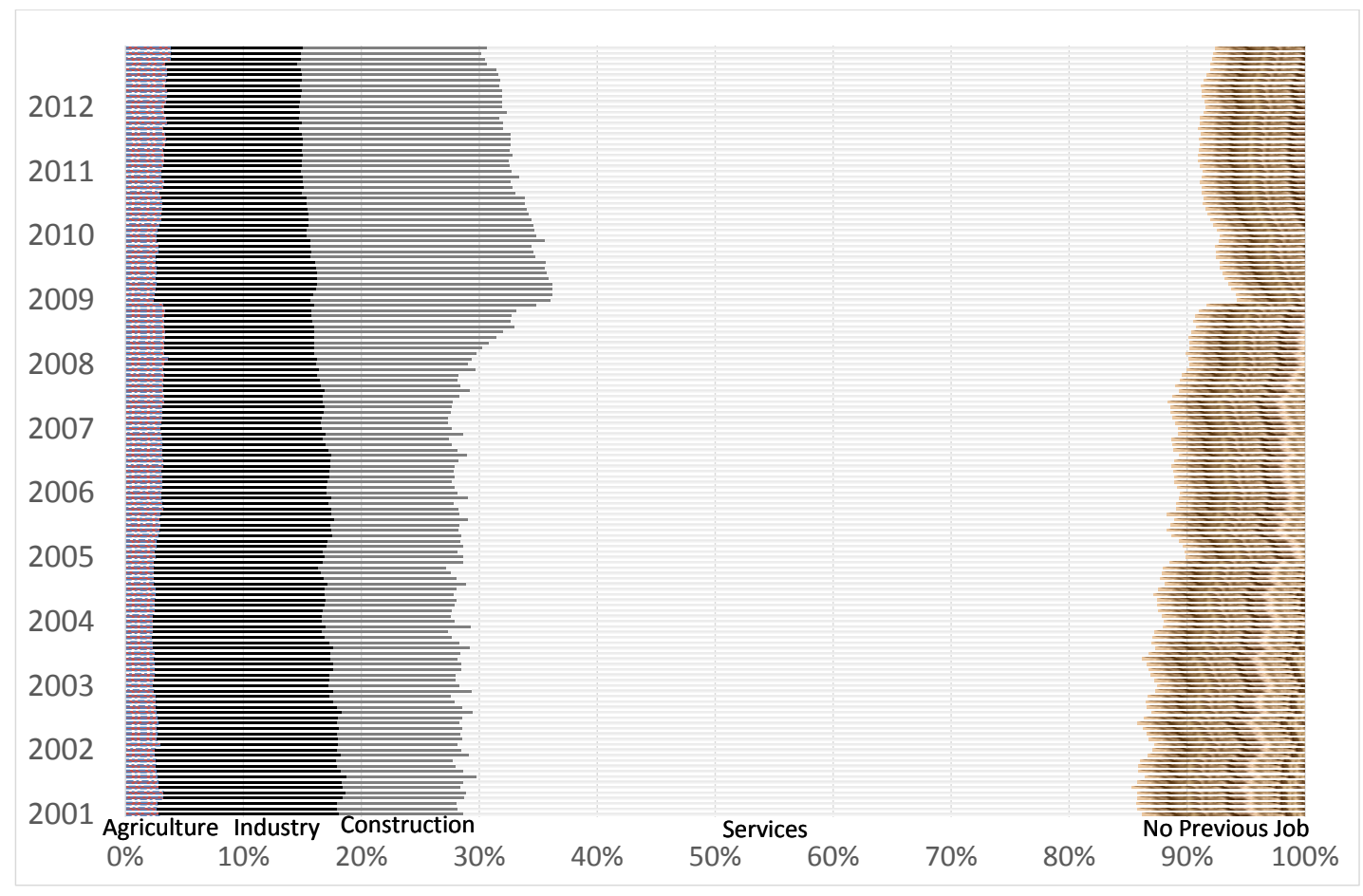

Source: Spanish Public Employment Service (Servicio Publico de Empleo Estatal). 
Figure 4: Unemployment and Employment in the Construction Sector

(a) Male Unemployment (Growth rate before/after the crisis)

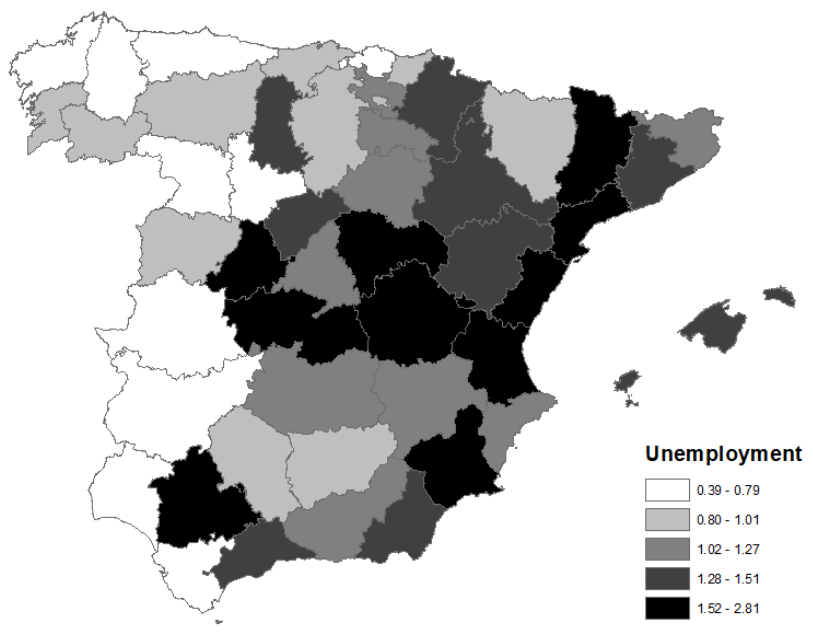

(b) Employment in the construction sector (Growth rate before/after the crisis)

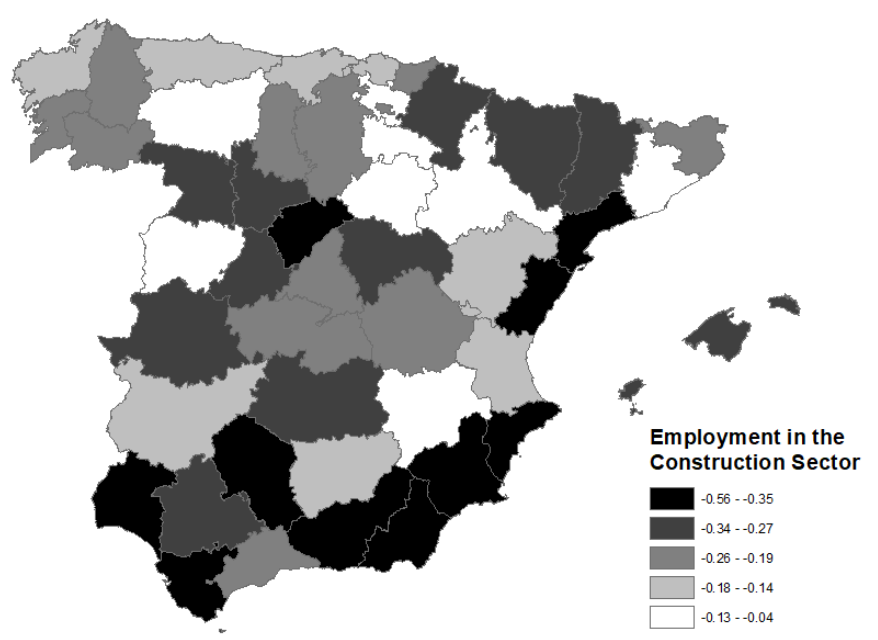

Note: The growth rates are constructed using, for each variable, the average provincial-quarter value before (2004-2007) and after (20082011) the crisis. In Figure (1), darker provinces are those affected by higher male unemployment growth rates, whereas in Figure (2), darker provinces are those that experienced a larger decrease in the employment rate in the construction sector. A negative sign indicates a decrease. 
Table 1: Descriptives

\begin{tabular}{|c|c|c|c|c|c|c|}
\hline & \multicolumn{3}{|c|}{ All Provinces } & \multicolumn{3}{|c|}{ No Large Cities } \\
\hline & Obs. & Mean & St.Dev & Obs. & Mean & St.Dev \\
\hline \multicolumn{7}{|c|}{ Panel A: Provincial-quarter Level } \\
\hline Accident rate & 1,600 & 0.482 & 0.196 & 1,472 & 0.473 & 0.196 \\
\hline Working day accident rate & 1,600 & 0.253 & 0.129 & 1,472 & 0.244 & 0.125 \\
\hline \multicolumn{7}{|l|}{ Panel B: Accident Level } \\
\hline Death & 730,606 & 0.033 & 0.202 & 409,760 & 0.046 & 0.240 \\
\hline Serious Injury & 730,606 & 0.194 & 0.494 & 409,760 & 0.247 & 0.554 \\
\hline Minor Injury & 730,606 & 1.237 & 0.980 & 409,760 & 1.234 & 1.055 \\
\hline No state street & 730,606 & 0.823 & 0.382 & 409,760 & 0.761 & 0.426 \\
\hline Working days & 730,606 & 0.565 & 0.496 & 409,760 & 0.527 & 0.499 \\
\hline Weekend & 730,606 & 0.266 & 0.442 & 409,760 & 0.293 & 0.455 \\
\hline Rush hours & 730,606 & 0.532 & 0.499 & 409,760 & 0.526 & 0.499 \\
\hline Good weather & 730,606 & 0.866 & 0.340 & 409,760 & 0.852 & 0.355 \\
\hline Dry\&Clean street & 730,606 & 0.851 & 0.356 & 409,760 & 0.829 & 0.377 \\
\hline Vehicles & 730,606 & 1.748 & 0.784 & 409,760 & 1.681 & 0.775 \\
\hline Pedestrians & 728,517 & 0.126 & 0.366 & 407,671 & 0.110 & 0.349 \\
\hline People in vehicles & 671,499 & 2.335 & 2.167 & 407,362 & 2.347 & 2.214 \\
\hline \multicolumn{7}{|c|}{ Panel C: Individual Level } \\
\hline Death & $1,752,029$ & 0.014 & 0.116 & 977,393 & 0.019 & 0.138 \\
\hline Serious Injury & $1,752,029$ & 0.081 & 0.272 & 977,393 & 0.104 & 0.305 \\
\hline Minor Injury & $1,752,029$ & 0.516 & 0.500 & 977,393 & 0.517 & 0.500 \\
\hline Spanish & $1,679,625$ & 0.853 & 0.354 & 942,520 & 0.863 & 0.343 \\
\hline Age & $1,614,270$ & 36.810 & 16.372 & 911,762 & 36.933 & 16.875 \\
\hline Age less 30 & $1,771,809$ & 0.354 & 0.478 & 987,656 & 0.365 & 0.482 \\
\hline Age 3060 & $1,771,809$ & 0.460 & 0.498 & 987,656 & 0.451 & 0.498 \\
\hline Age more 60 & $1,771,809$ & 0.175 & 0.380 & 987,656 & 0.174 & 0.379 \\
\hline Female & $1,733,700$ & 0.300 & 0.458 & 965,543 & 0.303 & 0.459 \\
\hline Alcohol & $1,752,029$ & 0.021 & 0.144 & 977,393 & 0.025 & 0.155 \\
\hline Stressed\&tired & $1,771,809$ & 0.006 & 0.078 & 987,656 & 0.009 & 0.094 \\
\hline Passenger & $1,752,029$ & 0.229 & 0.420 & 977,393 & 0.260 & 0.439 \\
\hline Precautions & $1,771,809$ & 0.646 & 0.478 & 987,656 & 0.686 & 0.464 \\
\hline Less driving experience & $1,771,809$ & 0.187 & 0.390 & 987,656 & 0.179 & 0.383 \\
\hline More driving experience & $1,771,809$ & 0.746 & 0.436 & 987,656 & 0.757 & 0.429 \\
\hline Maintenance problems & $1,771,809$ & 0.010 & 0.102 & 987,656 & 0.008 & 0.091 \\
\hline New vehicles & $1,771,809$ & 0.173 & 0.379 & 987,656 & 0.196 & 0.397 \\
\hline Short Trip & $1,679,625$ & 0.429 & 0.495 & 942,520 & 0.548 & 0.498 \\
\hline
\end{tabular}

Notes: Death, Serious Injury, and Minor Injury at the individual level are dummy variables, while at the accident level they are continuous variables that count the number of dead, seriously injured, and minor injured people for each accident. For a detailed explanation of each variable, see Table A1. The provincial-quarter level is computed by collapsing the data at the provincialquarter level and normalizing the value by 1,000 inhabitants. 


\section{Figure 5: Accident rates}

(a) Accident Rate (Growth rate before/after the crisis)

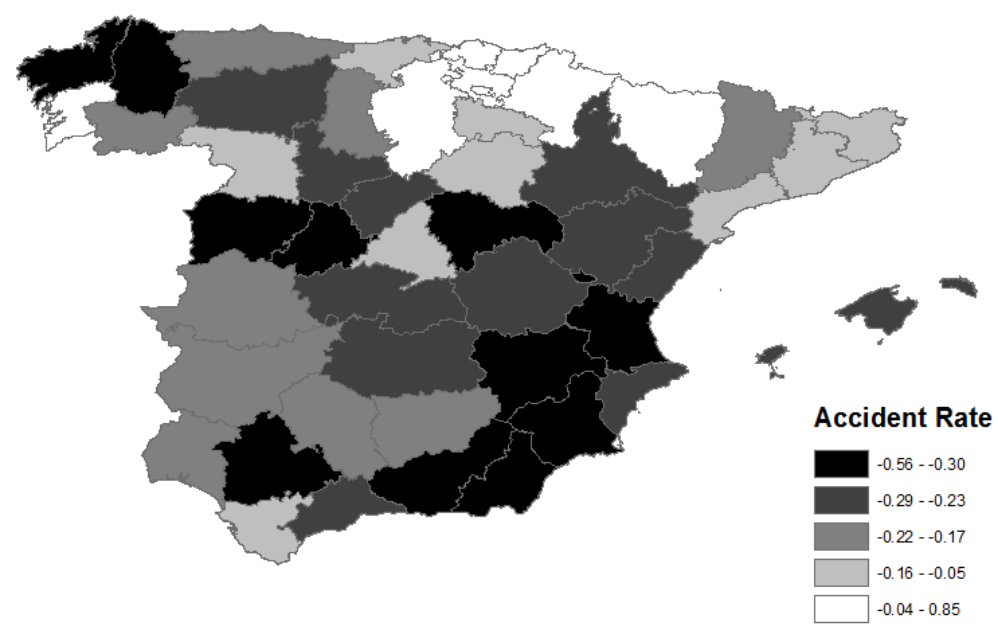

(b) Week Days Accident Rate (Growth rate before/after the crisis)

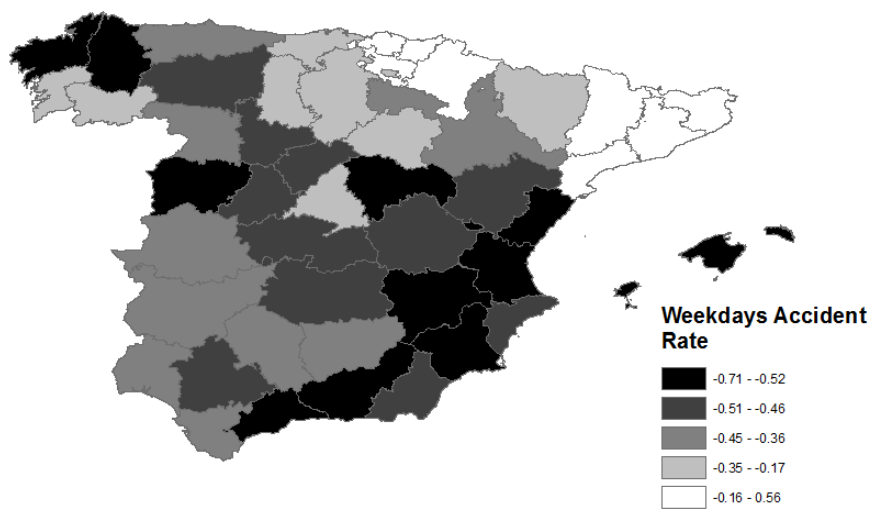

The growth rates are constructed using, for each variable, the average provincial-quarter value before (2004-2007) and after (2008-2011) the crisis. In both Figures (1) and (2), darker provinces are those with larger decreases in accident rates. A negative sign indicates a decrease. 


\section{Figure 6: Population trends}

(a) Population (Total)

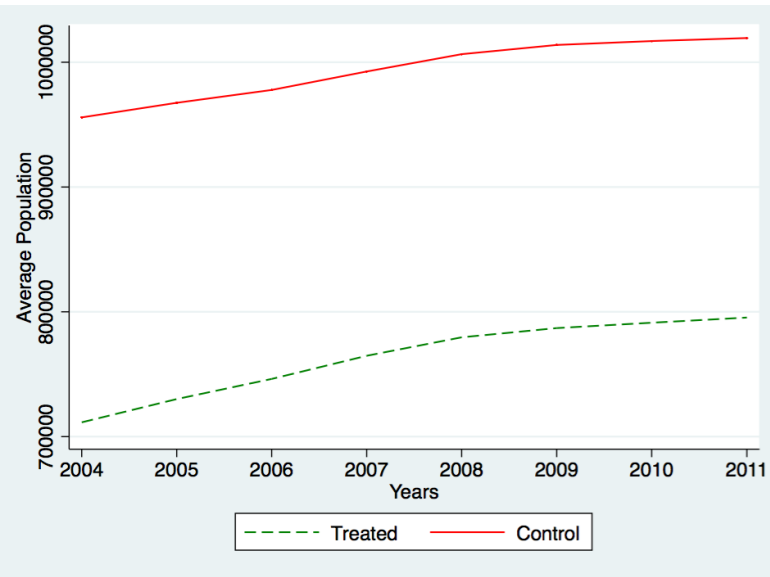

(b) Population (\% younger than 30$)$

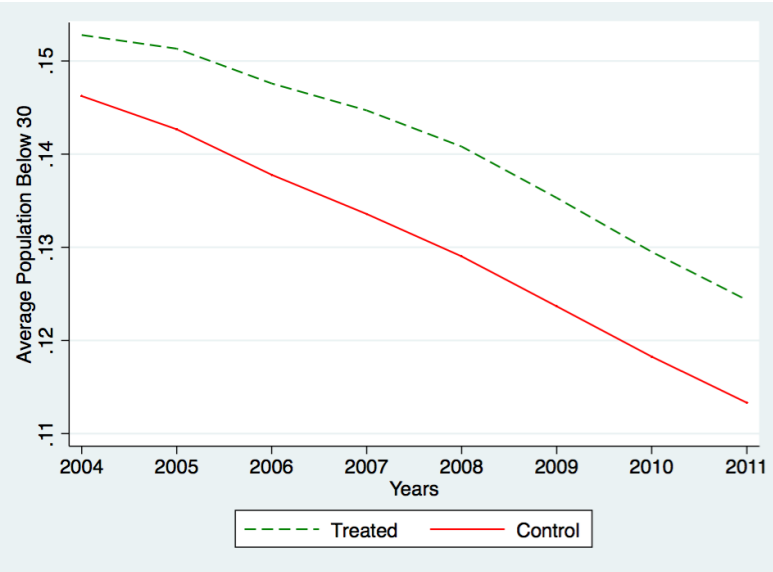

(c) Population (\% older than 30 and younger than $60)$

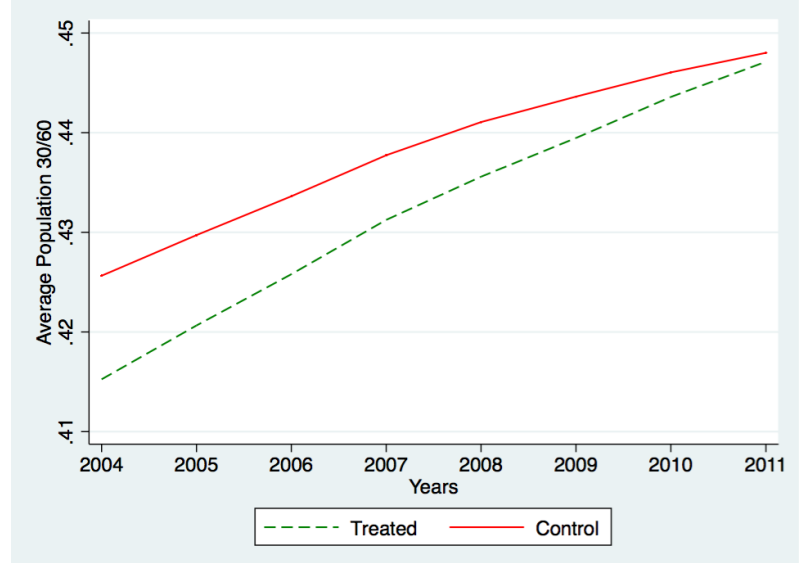

Note: These figures depict the trend in population at the provincial-year level for the treated and control provinces once we define treated and control according to the distribution of employment in the construction sector. 


\section{Figure 7: Accident rate trends}

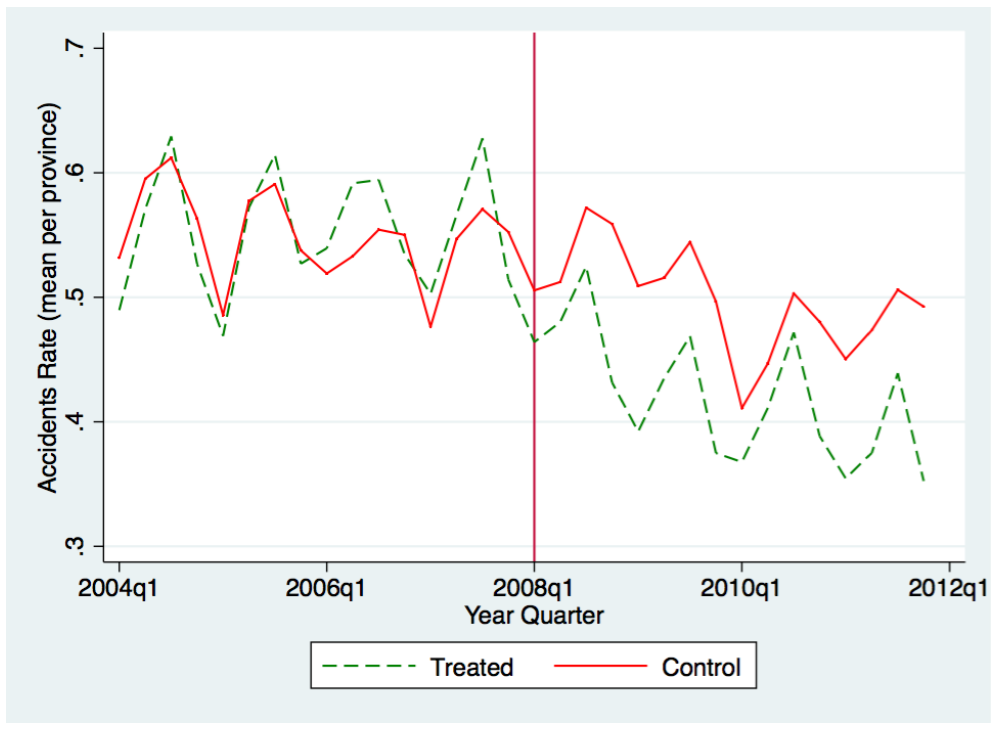

Note: We plot the provincial-quarter trends per treated and control of the number of accidents per 1,000 residents.

Table 2: Accident rates at the provincial-quarter level

\begin{tabular}{lcc}
\hline \hline & All & Working days \\
\hline \hline \multirow{2}{*}{ DD } & & \\
& & \\
Crisis & $-0.060^{* *}$ & $-0.039^{*}$ \\
& $(0.027)$ & $(0.022)$ \\
& & \\
\hline
\end{tabular}

Spatial panel fixed effects

\begin{tabular}{lcc} 
Crisis & $-0.064^{* * *}$ & $-0.041^{* *}$ \\
& $(0.025)$ & $(0.021)$ \\
$\lambda$ & $0.213^{* *}$ & $0.233^{* * *}$ \\
$\rho$ & 0.106 & $0.154^{*}$ \\
& & \\
Obs. & 1,600 & 1,600 \\
Mean & 0.482 & 0.253 \\
\hline
\end{tabular}

Notes: Crisis is the interaction between having a provincial level employment rate in the construction sector above the mean and the dummy for the period after the first quarter of 2008. $\lambda$ is the spatial autocorrelation parameter, and $\rho$ is the spatial autoregressive coefficient. Robust standard errors clustered at the provincial level in parentheses. Significance at the $10 \%$ level is represented by *, at the $5 \%$ level by ${ }^{* *}$, and at the $1 \%$ level by $* * *$. 
Figure 8: Leads and lags of accident rate

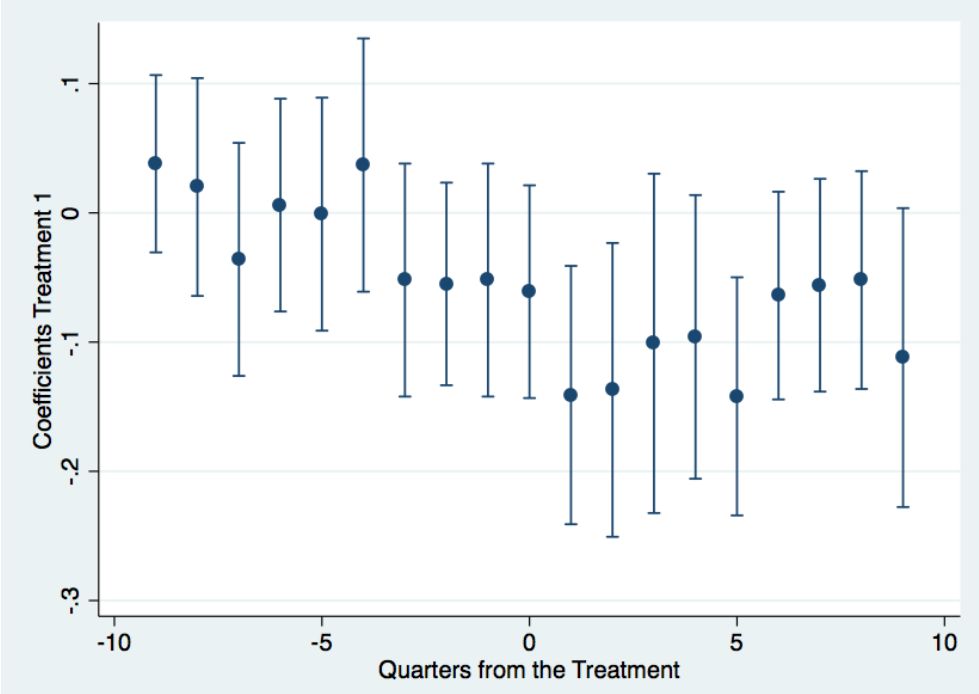

Note: The dots are the estimated coefficients for the quarters before and after the beginning of the crisis. The bars represent the confidence interval at the $5 \%$ significance level. 
Table 3: Severity of an accident (Individual \& vehicle levels)

\begin{tabular}{|c|c|c|c|c|c|c|}
\hline & \multicolumn{3}{|c|}{ All Provinces } & \multicolumn{3}{|c|}{ No Large Cities } \\
\hline & Death & Severe Injury & Minor Injury & Death & Severe Injury & Minor Injury \\
\hline Crisis & $\begin{array}{c}-0.003^{* * *} \\
(0.001)\end{array}$ & $\begin{array}{c}-0.017^{* * *} \\
(0.003)\end{array}$ & $\begin{array}{c}0.013^{* * *} \\
(0.005)\end{array}$ & $\begin{array}{c}-0.003^{* * *} \\
(0.001)\end{array}$ & $\begin{array}{c}-0.017^{* * *} \\
(0.003)\end{array}$ & $\begin{array}{c}0.018^{* * *} \\
(0.004)\end{array}$ \\
\hline Age & $\begin{array}{c}0.000^{* * *} * \\
(0.000)\end{array}$ & $\begin{array}{l}0.00^{* *} \\
(0.000)\end{array}$ & $\begin{array}{c}-0.003^{* * *} \\
(0.000)\end{array}$ & $\begin{array}{c}0.000^{* * *} \\
(0.000)\end{array}$ & $\begin{array}{c}0.000^{* * *} \\
(0.000)\end{array}$ & $\begin{array}{c}-0.002^{* * *} \\
(0.000)\end{array}$ \\
\hline Spanish & $\begin{array}{c}0.001 \\
(0.001)\end{array}$ & $\begin{array}{c}0.001 \\
(0.001)\end{array}$ & $\begin{array}{c}-0.013^{* *} \\
(0.006)\end{array}$ & $\begin{array}{c}0.001 \\
(0.001)\end{array}$ & $\begin{array}{c}0.016^{* * *} \\
(0.005)\end{array}$ & $\begin{array}{l}-0.011 \\
(0.008)\end{array}$ \\
\hline Female & $\begin{array}{c}-0.007^{* * *} \\
(0.000)\end{array}$ & $\begin{array}{c}-0.007^{* * *} \\
(0.000)\end{array}$ & $\begin{array}{c}0.116^{* * *} \\
(0.001)\end{array}$ & $\begin{array}{c}-0.009^{* * *} \\
(0.000)\end{array}$ & $\begin{array}{c}-0.027^{* * *} \\
(0.001)\end{array}$ & $\begin{array}{c}0.114^{* * *} \\
(0.002)\end{array}$ \\
\hline Alcohol & $\begin{array}{c}-0.011^{* * *} \\
(0.001)\end{array}$ & $\begin{array}{c}-0.011^{* * *} \\
(0.001)\end{array}$ & $\begin{array}{c}0.044^{* * *} \\
(0.004)\end{array}$ & $\begin{array}{c}-0.015^{* * * *} \\
(0.001)\end{array}$ & $\begin{array}{c}-0.020^{* * * *} \\
(0.003)\end{array}$ & $\begin{array}{c}0.047^{* * *} \\
(0.005)\end{array}$ \\
\hline Stressed\&tired & $\begin{array}{c}0.011^{* * *} \\
(0.002)\end{array}$ & $\begin{array}{c}0.011^{* * *} \\
(0.002)\end{array}$ & $\begin{array}{c}0.109^{* * *} \\
(0.006)\end{array}$ & $\begin{array}{c}0.010^{* * *} \\
(0.002)\end{array}$ & $\begin{array}{c}0.058^{* * *} \\
(0.004)\end{array}$ & $\begin{array}{c}0.104^{* * *} \\
(0.006)\end{array}$ \\
\hline Passengers & $\begin{array}{c}0.004^{* * *} \\
(0.000)\end{array}$ & $\begin{array}{c}0.004^{* * *} \\
(0.000)\end{array}$ & $\begin{array}{c}0.205^{* * *} \\
(0.008)\end{array}$ & $\begin{array}{c}0.005^{* * *} \\
(0.001)\end{array}$ & $\begin{array}{c}0.025^{* * *} \\
(0.002)\end{array}$ & $\begin{array}{c}0.185^{* * *} \\
(0.006)\end{array}$ \\
\hline Precautions & $\begin{array}{c}-0.007^{* * *} \\
(0.001)\end{array}$ & $\begin{array}{c}-0.007^{* * *} \\
(0.001)\end{array}$ & $\begin{array}{c}0.063^{* * *} \\
(0.003)\end{array}$ & $\begin{array}{c}-0.013^{* * *} \\
(0.001)\end{array}$ & $\begin{array}{c}-0.005^{* * *} \\
(0.002)\end{array}$ & $\begin{array}{c}0.070^{* * *} \\
(0.003)\end{array}$ \\
\hline Less driving experience & $\begin{array}{c}0.001^{* *} \\
(0.000)\end{array}$ & $\begin{array}{c}0.001^{* *} \\
(0.000)\end{array}$ & $\begin{array}{c}0.031^{* * *} \\
(0.002)\end{array}$ & $\begin{array}{c}0.002^{* *} \\
(0.001)\end{array}$ & $\begin{array}{c}0.011^{* * *} \\
(0.002)\end{array}$ & $\begin{array}{c}0.031^{* * *} \\
(0.002)\end{array}$ \\
\hline More driving experience & $\begin{array}{c}-0.001^{* * *} \\
(0.000)\end{array}$ & $\begin{array}{c}-0.001^{* * *} \\
(0.000)\end{array}$ & $\begin{array}{c}0.014^{* * *} \\
(0.002)\end{array}$ & $\begin{array}{c}-0.002^{* * *} \\
(0.001)\end{array}$ & $\begin{array}{c}0.003 \\
(0.002)\end{array}$ & $\begin{array}{c}0.022^{* * *} \\
(0.003)\end{array}$ \\
\hline Maintenance Problems & $\begin{array}{c}0.014^{* * *} \\
(0.002)\end{array}$ & $\begin{array}{c}0.014^{* * *} \\
(0.002)\end{array}$ & $\begin{array}{c}0.024^{* * *} \\
(0.006)\end{array}$ & $\begin{array}{c}0.020^{* * *} \\
(0.003)\end{array}$ & $\begin{array}{c}0.056^{* * *} \\
(0.006)\end{array}$ & $\begin{array}{c}0.018^{* *} \\
(0.007)\end{array}$ \\
\hline New Vehicles & $\begin{array}{c}0.001^{* *} \\
(0.000)\end{array}$ & $\begin{array}{c}0.001^{* *} \\
(0.000)\end{array}$ & $\begin{array}{c}-0.007^{* *} \\
(0.003)\end{array}$ & $\begin{array}{c}0.001 \\
(0.000)\end{array}$ & $\begin{array}{c}0.013^{* * *} \\
(0.001)\end{array}$ & $\begin{array}{c}-0.008^{* * *} \\
(0.002)\end{array}$ \\
\hline Short trip & $\begin{array}{c}-0.004^{* * *} \\
(0.001)\end{array}$ & $\begin{array}{c}-0.004^{* * *} \\
(0.001)\end{array}$ & $\begin{array}{c}0.008^{* * *} \\
(0.002)\end{array}$ & $\begin{array}{c}-0.006^{* * *} \\
(0.000)\end{array}$ & $\begin{array}{c}-0.009^{* * *} \\
(0.001)\end{array}$ & $\begin{array}{c}0.012^{* * * *} \\
(0.002)\end{array}$ \\
\hline Obs. & $1,529,402$ & $1,529,402$ & $1,529,402$ & 870,251 & 870,251 & 870,251 \\
\hline
\end{tabular}

Notes: The residual category for driving experience is those who have driving experience of between 5 and 10 years (see Table A1). The sample without large cities is defined by dropping the observations for the provinces of Madrid, Barcelona, Valencia, and Seville. In each specification, we control for quarter-year and the province fixed effects and provincial linear trends. Robust standard errors clustered at the province-quarter-year level in parentheses. Significance at the $10 \%$ level is represented by $*$, at the $5 \%$ level by $* *$, and at the $1 \%$ level by ***. 
Table 4: Severity of an accident (Accident level)

\begin{tabular}{|c|c|c|c|c|c|c|}
\hline & \multicolumn{3}{|c|}{ All Provinces } & \multicolumn{3}{|c|}{ No Large Cities } \\
\hline & Death & Severe Injury & Minor Injury & Death & Severe Injury & Minor Injury \\
\hline Crisis & $\begin{array}{c}-0.007 * * * \\
(0.001)\end{array}$ & $\begin{array}{c}-0.041^{* * *} \\
(0.006)\end{array}$ & $\begin{array}{c}0.021^{* *} \\
(0.010)\end{array}$ & $\begin{array}{c}-0.008^{* * *} \\
(0.002)\end{array}$ & $\begin{array}{c}-0.046 * * * \\
(0.007)\end{array}$ & $\begin{array}{c}0.033^{* * *} \\
(0.010)\end{array}$ \\
\hline Working_day & $\begin{array}{c}-0.002^{* *} \\
(0.001)\end{array}$ & $\begin{array}{c}-0.009^{* * *} \\
(0.003)\end{array}$ & $\begin{array}{c}-0.028^{* * *} \\
(0.004)\end{array}$ & $\begin{array}{l}-0.002^{*} \\
(0.001)\end{array}$ & $\begin{array}{c}-0.013^{* * *} \\
(0.003)\end{array}$ & $\begin{array}{c}-0.026^{* * *} \\
(0.004)\end{array}$ \\
\hline Weekend & $\begin{array}{c}0.008^{* * *} \\
(0.001)\end{array}$ & $\begin{array}{c}0.041^{* * *} \\
(0.003)\end{array}$ & $\begin{array}{c}0.079^{* * *} \\
(0.005)\end{array}$ & $\begin{array}{c}0.008^{* * *} \\
(0.001)\end{array}$ & $\begin{array}{c}0.043^{* * *} \\
(0.003)\end{array}$ & $\begin{array}{c}0.062^{* * *} \\
(0.006)\end{array}$ \\
\hline Rush_Hours & $\begin{array}{c}-0.008^{* * *} \\
(0.001)\end{array}$ & $\begin{array}{c}-0.014^{* * *} \\
(0.001)\end{array}$ & $\begin{array}{c}-0.016^{* * *} \\
(0.002)\end{array}$ & $\begin{array}{c}-0.009^{* * *} \\
(0.001)\end{array}$ & $\begin{array}{c}-0.015^{* * *} \\
(0.002)\end{array}$ & $\begin{array}{c}-0.012^{* * *} \\
(0.003)\end{array}$ \\
\hline No State Street & $\begin{array}{c}-0.030 * * * \\
(0.002)\end{array}$ & $\begin{array}{c}-0.046^{* * *} \\
(0.005)\end{array}$ & $\begin{array}{c}-0.046^{* * *} \\
(0.009)\end{array}$ & $\begin{array}{c}-0.031^{* * *} \\
(0.002)\end{array}$ & $\begin{array}{c}-0.048^{* * *} \\
(0.005)\end{array}$ & $\begin{array}{c}-0.052^{* * *} \\
(0.007)\end{array}$ \\
\hline Good Weather & $\begin{array}{c}-0.007^{* * *} \\
(0.001)\end{array}$ & $\begin{array}{c}-0.007^{*} \\
(0.004)\end{array}$ & $\begin{array}{c}-0.011^{*} \\
(0.006)\end{array}$ & $\begin{array}{c}-0.009^{* * *} \\
(0.002)\end{array}$ & $\begin{array}{l}-0.008 \\
(0.005)\end{array}$ & $\begin{array}{c}-0.018^{* *} \\
(0.008)\end{array}$ \\
\hline Dry\&Clean Street & $\begin{array}{c}0.003^{* *} \\
(0.001)\end{array}$ & $\begin{array}{c}0.026^{* * *} \\
(0.004)\end{array}$ & $\begin{array}{c}-0.074^{* * *} \\
(0.006)\end{array}$ & $\begin{array}{c}0.003^{*} \\
(0.002)\end{array}$ & $\begin{array}{c}0.027^{* * *} \\
(0.005)\end{array}$ & $\begin{array}{c}-0.069^{* * *} \\
(0.007)\end{array}$ \\
\hline Vehicles & $\begin{array}{c}-0.007^{* * *} \\
(0.001)\end{array}$ & $\begin{array}{c}-0.038^{* * *} \\
(0.003)\end{array}$ & $\begin{array}{c}0.106^{* * *} \\
(0.019)\end{array}$ & $\begin{array}{c}-0.008^{* * *} \\
(0.001)\end{array}$ & $\begin{array}{c}-0.043^{* * *} \\
(0.004)\end{array}$ & $\begin{array}{c}0.101^{* * *} \\
(0.019)\end{array}$ \\
\hline N. of People in Vehicles & $\begin{array}{c}0.005^{* * *} \\
(0.001)\end{array}$ & $\begin{array}{c}0.023^{* * *} \\
(0.002)\end{array}$ & $\begin{array}{c}0.185^{* * *} \\
(0.016)\end{array}$ & $\begin{array}{c}0.006^{* * *} \\
(0.001)\end{array}$ & $\begin{array}{c}0.028^{* * *} \\
(0.002)\end{array}$ & $\begin{array}{c}0.203^{* * *} \\
(0.015)\end{array}$ \\
\hline Obs. & 671,499 & 671,499 & 671,499 & 407,362 & 407,362 & 407,362 \\
\hline
\end{tabular}

Notes: The sample without large cities is defined by dropping the observations for the provinces of Madrid, Barcelona, Valencia, and Seville. In each specification, we control for quarter-year and province fixed effects and provincial linear trends. Robust standard errors clustered at the province-quarter-year level in parentheses. Significance at the $10 \%$ level is represented by *, at the $5 \%$ level by $* *$, and at the $1 \%$ level by ***. 
Table 5: Characteristics of the people involved

\begin{tabular}{lcccc}
\hline \hline Panel A: & Age & & & \\
& Age & Age less 30 & Age 30 to 60 & Older than 60 \\
Crisis & $0.195^{* *}$ & $-0.011^{* * *}$ & $-0.014^{* * *}$ & $0.023^{* * *}$ \\
& $(0.097)$ & $(0.004)$ & $(0.004)$ & $(0.006)$ \\
Obs. & $1,614,270$ & $1,614,270$ & $1,614,270$ & $1,614,270$ \\
\hline \multicolumn{2}{c}{ Panel B: Conditions } & & & \\
& Alcohol & Stressed \&Tired & Female & Spanish \\
Crisis & $0.004^{* * *}$ & 0.000 & 0.003 & 0.016 \\
& $(0.001)$ & $(0.000)$ & $(0.002)$ & $(0.012)$ \\
Obs. & $1,752,029$ & $1,771,809$ & $1,733,700$ & $1,679,625$ \\
\hline
\end{tabular}

\begin{tabular}{|c|c|c|c|c|}
\hline \multicolumn{5}{|c|}{ Panel C: Driving behavior \& experience } \\
\hline & Precautions & Less Driving Experience & More Driving Experience & \\
\hline Crisis & $\begin{array}{c}0.001 \\
(0.011)\end{array}$ & $\begin{array}{c}-0.014^{* *} \\
(0.007)\end{array}$ & $\begin{array}{c}0.020^{* *} \\
(0.009)\end{array}$ & \\
\hline Obs. & $1,184,028$ & $1,257,838$ & $1,257,838$ & \\
\hline \multicolumn{5}{|c|}{ Panel D: Age of the drivers } \\
\hline & Age & Age less 30 & Age 30 to 60 & Older than 60 \\
\hline Crisis & $\begin{array}{c}0.253^{* * *} \\
(0.093)\end{array}$ & $\begin{array}{c}-0.009^{* * *} \\
(0.003)\end{array}$ & $\begin{array}{c}-0.010^{* *} \\
(0.004)\end{array}$ & $\begin{array}{c}0.019^{* * *} \\
(0.005)\end{array}$ \\
\hline Obs. & $1,184,028$ & $1,184,028$ & $1,184,028$ & $1,184,028$ \\
\hline \multicolumn{5}{|c|}{ Panel E: Conditions of the driver } \\
\hline & Alcohol & Stressed\&Tired & Female & Spanish \\
\hline Crisis & $\begin{array}{c}0.006^{* * *} \\
(0.001)\end{array}$ & $\begin{array}{c}0 \\
(0.001)\end{array}$ & $\begin{array}{c}0.002 \\
(0.002)\end{array}$ & $\begin{array}{l}0.023^{*} \\
(0.012)\end{array}$ \\
\hline Obs. & $1,257,838$ & $1,257,838$ & $1,247,127$ & $1,257,838$ \\
\hline
\end{tabular}

Panel F: Driving behavior \& experience of the driver Precautions Less Driving Experience More Driving Experience

\begin{tabular}{cccc} 
Crisis & 0.002 & $-0.017^{*}$ & $0.024^{*}$ \\
& $(0.012)$ & $(0.010)$ & $(0.013)$ \\
Obs. & $1,257,838$ & $1,257,838$ & $1,257,838$ \\
\hline
\end{tabular}

Notes: Robust standard errors clustered at the province-quarter-year level in parentheses. In each specification, we control for quarter-year and province fixed effects and provincial linear trends. Significance at the $10 \%$ level is represented by $*$, at the $5 \%$ level by ${ }^{* *}$, and at the $1 \%$ level by ***. 


\section{Table 6: Vehicles and accident context}

$\begin{array}{lccc}\text { Panel A: Number of vehicles } & & \\ & \text { Vehicles } & \text { Pedestrians } & \text { People in the vehicle } \\ \text { Crisis } & -0.016^{* * *} & 0.011^{* * *} & 0.068^{* *} \\ & (0.006) & (0.003) & (0.031) \\ \text { Obs. } & 730,606 & 728,517 & 671,499\end{array}$

\begin{tabular}{lcc} 
Panel B: Conditions & \\
& Maintenance Problems & New Vehicle \\
Crisis & $-0.004^{* * *}$ & $-0.023^{* * *}$ \\
& $(0.001)$ & $(0.007)$ \\
Obs. & $1,771,809$ & $1,771,809$ \\
\hline
\end{tabular}

Panel C: Timing and type of accident

Rush Hours Working Days Weekend

\begin{tabular}{lccc} 
Crisis & $-0.006^{* *}$ & $-0.040^{* * *}$ & -0.000 \\
& $(0.002)$ & $(0.013)$ & $(0.003)$ \\
Obs. & 730,606 & 730,606 & 730,606 \\
\hline
\end{tabular}

Panel D: Weather and street status

Good Weather Dry \& Clean Street

\begin{tabular}{lcc} 
Crisis & 0.012 & 0.006 \\
& $(0.010)$ & $(0.005)$ \\
Obs. & 730,606 & 730,606 \\
\hline
\end{tabular}

Panel E: Motive of the trip Short Trip No State Street

\begin{tabular}{ccc} 
Crisis & $0.027^{* * *}$ & 0.041 \\
& $(0.006)$ & $(0.025)$ \\
& & \\
Obs. & $1,679,625$ & 730,606 \\
\hline
\end{tabular}

Notes: Robust standard errors clustered at the province-quarter level in parentheses. In each specification, we control for quarter-year and province fixed effects and provincial linear trends. Significance at the $10 \%$ level is represented by $*$, at the $5 \%$ level by ${ }^{*}$, and at the $1 \%$ level by $* * *$. 
Table 7: Characteristics of the people involved (No large cities)

\begin{tabular}{|c|c|c|c|c|}
\hline \multicolumn{5}{|c|}{ Panel A: Age } \\
\hline & Age & Age less 30 & Age 30 to 60 & Older than 60 \\
\hline Crisis & $\begin{array}{c}0.384^{* * *} \\
(0.103)\end{array}$ & $\begin{array}{c}-0.016^{* * *} \\
(0.005)\end{array}$ & $\begin{array}{c}0.001 \\
(0.006)\end{array}$ & $\begin{array}{c}0.016 \\
(0.011)\end{array}$ \\
\hline Obs. & 911,762 & 911,762 & 911,762 & 911,762 \\
\hline \multicolumn{5}{|c|}{ Panel B: Conditions } \\
\hline & Alcohol & Stressed/\&Tired & Female & Spanish \\
\hline Crisis & $\begin{array}{c}0.001 \\
(0.001)\end{array}$ & $\begin{array}{c}-0.002^{* * *} \\
(0.001)\end{array}$ & $\begin{array}{c}0.007^{* * *} \\
(0.002)\end{array}$ & $\begin{array}{c}-0.025^{*} \\
(0.013)\end{array}$ \\
\hline Obs. & 977,393 & 987,656 & 942,520 & 965,543 \\
\hline
\end{tabular}

Panel C: Driving behavior \& experience Precautions Less Driving Experience More Driving Experience

$\begin{array}{lccc}\text { Crisis } & 0.026^{* * *} & -0.037^{* * *} & 0.047^{* * *} \\ & (0.007) & (0.007) & (0.009) \\ \text { Obs. } & 987,656 & 987,656 & 987,656\end{array}$

Panel D: Age of the drivers

$\begin{array}{lll}\text { Age } & \text { Age less } 30 & \text { Age } 30 \text { to } 60 \quad \text { Older than } 60\end{array}$

\begin{tabular}{ccccc} 
Crisis & $0.541^{* * *}$ & $-0.021^{* * *}$ & -0.023 & $0.021^{* *}$ \\
& $(0.091)$ & $(0.005)$ & $(0.007)$ & $(0.01)$ \\
Obs. & 649,143 & 649,143 & 649,143 & 649,143 \\
\hline
\end{tabular}

Panel E: Conditions of the driver

Alcohol Stressed/\&Tired Female Spanish

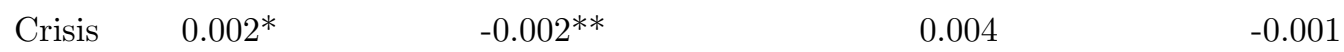

$\begin{array}{llll}(0.001) & (0.001) & (0.002)\end{array}$

$\begin{array}{lllll}\text { Obs. } & 678,301 & 678,301 & 671,855 & 678,301\end{array}$

Panel F: Driving behavior \& experience of the driver Precautions Less Driving Experience More Driving Experience

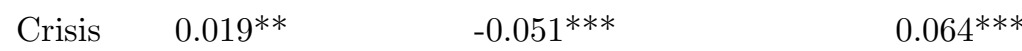

$(0.008) \quad(0.01) \quad(0.012)$

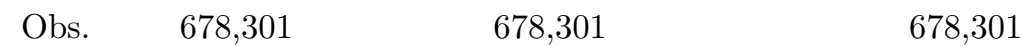

Notes: The sample is defined by dropping the observations for the provinces of Madrid, Barcelona, Valencia, and Seville. In each specification, we control for quarter-year and province fixed effects and provincial linear trends. Robust standard errors clustered at the province-quarter-year level in parentheses. Significance at the $10 \%$ level is represented by $*$, at the $5 \%$ level by **, and at the $1 \%$ level by *** . 
Table 8: Vehicles and accident context (No large cities)

\begin{tabular}{|c|c|c|c|}
\hline \multicolumn{4}{|c|}{ Panel A: Number of vehicles } \\
\hline Crisis & $\begin{array}{c}0.004 \\
(0.006)\end{array}$ & $\begin{array}{c}-0.008^{* *} \\
(0.004)\end{array}$ & $\begin{array}{c}0.131^{* * *} \\
(0.039)\end{array}$ \\
\hline Obs. & 409,760 & 407,671 & 407,362 \\
\hline \multicolumn{4}{|c|}{ Panel B: Conditions } \\
\hline Crisis & $\begin{array}{c}-0.003^{* * *} \\
(0.001)\end{array}$ & $\begin{array}{c}-0.019^{* * *} \\
(0.005)\end{array}$ & \\
\hline Obs. & 409,760 & 409,760 & \\
\hline \multicolumn{4}{|c|}{ Panel C: Timing and type of accident } \\
\hline & Rush Hours & Working Days & Weekend \\
\hline Crisis & $\begin{array}{c}-0.002 \\
(0.003)\end{array}$ & $\begin{array}{l}-0.012 \\
(0.010)\end{array}$ & $\begin{array}{l}-0.004 \\
(0.003)\end{array}$ \\
\hline Obs. & 409,760 & 409,760 & 409,760 \\
\hline
\end{tabular}

Panel D: Weather and street status

Good Weather Dry \& Clean Street

\begin{tabular}{lcc} 
Crisis & $-0.014^{* *}$ & $-0.015^{* * *}$ \\
& $(0.006)$ & $(0.005)$ \\
Obs. & 409,760 & 409,760 \\
\hline
\end{tabular}

Panel E: Motive of the trip Short Trip No State Street

$\begin{array}{ccc}\text { Crisis } & -0.054^{* * *} & 0.009 \\ & (0.016) & (0.007)\end{array}$

Obs. $\quad 977,393 \quad 409,760$

Notes: The sample is defined by dropping the observations for the provinces of Madrid, Barcelona, Valencia, and Seville. In each specification, we control for quarter-year and province fixed effects and provincial linear trends. Robust standard errors clustered at the provincequarter level in parenthesis. Significance at the $10 \%$ level is represented by *, at the $5 \%$ level by $* *$, and at the $1 \%$ level by $* * *$. 
Table 9: Robustness using alternative definitions of treatment on accident severity

\begin{tabular}{|c|c|c|c|c|c|c|}
\hline & \multicolumn{3}{|c|}{ All Provinces } & \multicolumn{3}{|c|}{ No Large Cities } \\
\hline & Death & Severe Injury & Minor Injury & Death & Severe Injury & Minor Injury \\
\hline \multicolumn{7}{|c|}{ Individual \& vehicle level } \\
\hline \multicolumn{7}{|c|}{ Panel A: Crisis=Level of employment in the construction sector (Continuous) $*$ Post200 } \\
\hline Crisis & $\begin{array}{c}-0.000^{* * *} \\
(0.000)\end{array}$ & $\begin{array}{c}-0.002^{* * *} \\
(0.001)\end{array}$ & $\begin{array}{c}0.002^{* *} \\
(0.001)\end{array}$ & $\begin{array}{c}-0.000^{* *} \\
(0.000)\end{array}$ & $\begin{array}{c}-0.002^{* * *} \\
(0.001)\end{array}$ & $\begin{array}{c}0.003^{* * *} \\
(0.001)\end{array}$ \\
\hline \multicolumn{7}{|c|}{ Panel B: Crisis=Level of overall unemployment (Continuous)*Post2008 } \\
\hline Crisis & $\begin{array}{c}-0.000^{* * *} \\
(0.000)\end{array}$ & $\begin{array}{c}-0.002^{* * *} \\
(0.000)\end{array}$ & $\begin{array}{c}0.001^{* *} \\
(0.001)\end{array}$ & $\begin{array}{c}-0.000^{* * *} \\
(0.000)\end{array}$ & $\begin{array}{c}-0.002^{* * *} \\
(0.000)\end{array}$ & $\begin{array}{c}0.002^{* * *} \\
(0.000)\end{array}$ \\
\hline Obs. & $1,529,402$ & $1,529,402$ & $1,529,402$ & 870,251 & 870,251 & 870,251 \\
\hline
\end{tabular}

Accident level

Panel C: Crisis=Level of employment in the construction sector (Continuous)*Post2008

$\begin{array}{ccccccc}\text { Crisis } & -0.001^{* * *} & -0.005^{* * *} & 0.001 & -0.001^{* * *} & -0.006^{* * *} & 0.002 \\ & (0.000) & (0.001) & (0.002) & (0.000) & (0.001) & (0.002)\end{array}$

Panel D: Crisis=Level of overall unemployment (Continuous)*Post2008

\begin{tabular}{ccccccc} 
Crisis & $-0.001^{* * *}$ & $-0.004^{* * *}$ & 0.000 & $-0.001^{* * *}$ & $-0.005^{* * *}$ & 0.000 \\
& $(0.000)$ & $(0.001)$ & $(0.001)$ & $(0.000)$ & $(0.001)$ & $(0.001)$ \\
& & & & & & \\
Obs. & 671,499 & 671,499 & 671,499 & 407,362 & 407,362 & 407,362 \\
\hline
\end{tabular}

Notes: These coefficients are generated replicating the results of Tables 3 and 4 using alternative definitions of treatments. The sample without the large cities is defined by dropping the observations for the provinces of Madrid, Barcelona, Valencia, and Seville. In each specification, we control for quarter-year and province fixed effects and provincial linear trends. Robust standard errors clustered at the province-quarter-year level in parentheses. Significance at the $10 \%$ level is represented by *, at the $5 \%$ level by $* *$, and at the $1 \%$ level by $* * *$. 
Table 10: Robustness using alternative specifications of accident severity

\begin{tabular}{|c|c|c|c|c|c|c|}
\hline & \multicolumn{3}{|c|}{ All Provinces } & \multicolumn{3}{|c|}{ No Large Cities } \\
\hline & Death & Severe Injury & Minor Injury & Death & Severe Injury & Minor Injury \\
\hline \multicolumn{7}{|c|}{ Individual \& vehicle level } \\
\hline \multicolumn{7}{|c|}{ Panel A: Control for weekdays fixed effects } \\
\hline Crisis & $\begin{array}{c}-0.003^{* * *} \\
(0.001)\end{array}$ & $\begin{array}{c}-0.017^{* * *} \\
(0.003)\end{array}$ & $\begin{array}{c}0.013^{* * *} \\
(0.005)\end{array}$ & $\begin{array}{c}-0.003^{* *} \\
(0.001)\end{array}$ & $\begin{array}{c}-0.017^{* * * *} \\
(0.003)\end{array}$ & $\begin{array}{c}0.018^{* * *} \\
(0.004)\end{array}$ \\
\hline \multicolumn{7}{|c|}{ Panel B: Control for weather conditions } \\
\hline Crisis & $\begin{array}{c}-0.003^{* * *} \\
(0.001)\end{array}$ & $\begin{array}{c}-0.017^{* * *} \\
(0.003)\end{array}$ & $\begin{array}{c}0.013^{* * *} \\
(0.005)\end{array}$ & $\begin{array}{c}-0.003^{* * *} \\
(0.001)\end{array}$ & $\begin{array}{c}-0.017^{* * *} \\
(0.003)\end{array}$ & $\begin{array}{c}0.018^{* * *} \\
(0.004)\end{array}$ \\
\hline \multicolumn{7}{|c|}{ Panel C: Control for weekdays fixed effects \& weather conditions } \\
\hline Crisis & $\begin{array}{c}-0.003^{* * *} \\
(0.001)\end{array}$ & $\begin{array}{c}-0.017^{* * *} \\
(0.003)\end{array}$ & $\begin{array}{c}0.013^{* * *} \\
(0.005)\end{array}$ & $\begin{array}{c}-0.003^{* * *} \\
(0.001)\end{array}$ & $\begin{array}{c}-0.017^{* * *} \\
(0.003)\end{array}$ & $\begin{array}{c}0.018^{* * *} \\
(0.004)\end{array}$ \\
\hline \multicolumn{7}{|c|}{ Panel D: Two-way clustering } \\
\hline Crisis & $\begin{array}{c}-0.003^{* * *} \\
(0.001)\end{array}$ & $\begin{array}{c}-0.017^{* * *} \\
(0.004)\end{array}$ & $\begin{array}{c}0.013 \\
(0.012)\end{array}$ & $\begin{array}{c}-0.003^{*} \\
(0.001)\end{array}$ & $\begin{array}{c}-0.017^{* * *} \\
(0.006)\end{array}$ & $\begin{array}{l}0.018^{*} \\
(0.009)\end{array}$ \\
\hline \multicolumn{7}{|c|}{ Panel E: Two-way clustering \& weekdays fixed effects } \\
\hline Crisis & $\begin{array}{c}-0.003^{* * *} \\
(0.001)\end{array}$ & $\begin{array}{c}-0.017^{* * *} \\
(0.004)\end{array}$ & $\begin{array}{c}0.013 \\
(0.012)\end{array}$ & $\begin{array}{c}-0.003^{*} \\
(0.001)\end{array}$ & $\begin{array}{c}-0.017^{* * * *} \\
(0.006)\end{array}$ & $\begin{array}{l}0.018^{*} \\
(0.009)\end{array}$ \\
\hline \multicolumn{7}{|c|}{ Panel F: Two-way clustering \& weather conditions } \\
\hline Crisis & $\begin{array}{c}-0.003^{* * *} \\
(0.001)\end{array}$ & $\begin{array}{c}-0.017 * * * \\
(0.004)\end{array}$ & $\begin{array}{c}0.013 \\
(0.012)\end{array}$ & $\begin{array}{c}-0.003^{*} \\
(0.001)\end{array}$ & $\begin{array}{c}-0.017^{* * *} \\
(0.006)\end{array}$ & $\begin{array}{l}0.018^{*} \\
(0.010)\end{array}$ \\
\hline \multicolumn{7}{|c|}{ Panel G: Two-way clustering, weekdays fixed effects \& weather conditions } \\
\hline Crisis & $\begin{array}{c}-0.003^{* * *} \\
(0.001)\end{array}$ & $\begin{array}{c}-0.017^{* * *} \\
(0.004)\end{array}$ & $\begin{array}{c}0.013 \\
(0.012)\end{array}$ & $\begin{array}{c}-0.003^{*} \\
(0.001)\end{array}$ & $\begin{array}{c}-0.017^{* * *} \\
(0.006)\end{array}$ & $\begin{array}{l}0.018^{*} \\
(0.010)\end{array}$ \\
\hline Obs. & $1,529,402$ & $1,529,402$ & $1,529,402$ & 870,251 & 870,251 & 870,251 \\
\hline \multicolumn{7}{|c|}{ Accident level } \\
\hline \multicolumn{7}{|c|}{ Panel H: Control for weekdays fixed effects } \\
\hline Crisis & $\begin{array}{c}-0.007^{* * *} \\
(0.001)\end{array}$ & $\begin{array}{c}-0.041^{* * *} \\
(0.006)\end{array}$ & $\begin{array}{l}0.022^{* *} \\
(0.010)\end{array}$ & $\begin{array}{c}-0.008^{* * *} \\
(0.002)\end{array}$ & $\begin{array}{c}-0.046^{* * *} \\
(0.007)\end{array}$ & $\begin{array}{c}0.033^{* * * *} \\
(0.010)\end{array}$ \\
\hline \multicolumn{7}{|c|}{ Panel I: Control for weather conditions } \\
\hline Crisis & $\begin{array}{c}-0.007^{* * *} \\
(0.001)\end{array}$ & $\begin{array}{c}-0.041^{* * * *} \\
(0.006)\end{array}$ & $\begin{array}{c}0.022^{* *} \\
(0.010)\end{array}$ & $\begin{array}{c}-0.008^{* * * *} \\
(0.002)\end{array}$ & $\begin{array}{c}-0.046^{* * *} \\
(0.007)\end{array}$ & $\begin{array}{c}0.033^{* * *} \\
(0.010)\end{array}$ \\
\hline \multicolumn{7}{|c|}{ Panel J: Control for weather conditions \& weather conditions } \\
\hline Crisis & $\begin{array}{c}-0.007^{* * *} \\
(0.001)\end{array}$ & $\begin{array}{c}-0.041^{* * *} \\
(0.006)\end{array}$ & $\begin{array}{c}0.022^{* *} \\
(0.010)\end{array}$ & $\begin{array}{c}-0.008^{* * *} \\
(0.002)\end{array}$ & $\begin{array}{c}-0.046^{* * *} \\
(0.007)\end{array}$ & $\begin{array}{c}0.033^{* * *} \\
(0.010)\end{array}$ \\
\hline \multicolumn{7}{|c|}{ Panel K: Two-way clustering } \\
\hline Crisis & $\begin{array}{c}-0.007^{* * *} \\
(0.002)\end{array}$ & $\begin{array}{c}-0.041^{* * *} \\
(0.009)\end{array}$ & $\begin{array}{c}0.022 \\
(0.019)\end{array}$ & $\begin{array}{c}-0.008^{* *} \\
(0.004)\end{array}$ & $\begin{array}{c}-0.046^{* * *} \\
(0.015)\end{array}$ & $\begin{array}{c}0.033 \\
(0.022)\end{array}$ \\
\hline \multicolumn{7}{|c|}{ Panel L: Two-way clustering \& weekdays fixed effects } \\
\hline Crisis & $\begin{array}{c}-0.007^{* * *} \\
(0.002)\end{array}$ & $\begin{array}{c}-0.041 * * * \\
(0.009)\end{array}$ & $\begin{array}{c}0.022 \\
(0.019)\end{array}$ & $\begin{array}{c}-0.008^{* *} \\
(0.004)\end{array}$ & $\begin{array}{c}-0.046^{* * *} \\
(0.015)\end{array}$ & $\begin{array}{c}0.033 \\
(0.022)\end{array}$ \\
\hline \multicolumn{7}{|c|}{ Panel M: Two-way clustering \& weather conditions } \\
\hline Crisis & $\begin{array}{c}-0.007^{* * *} \\
(0.002)\end{array}$ & $\begin{array}{c}-0.041 * * * \\
(0.009)\end{array}$ & $\begin{array}{c}0.022 \\
(0.019)\end{array}$ & $\begin{array}{c}-0.008^{* *} \\
(0.004)\end{array}$ & $\begin{array}{c}-0.046^{* * *} \\
(0.015)\end{array}$ & $\begin{array}{c}0.033 \\
(0.022)\end{array}$ \\
\hline Panel & N: Two-w & clustering, & veekdays fixec & ects \& wea & her condition & \\
\hline Crisis & $\begin{array}{c}-0.007^{* * *} \\
(0.002)\end{array}$ & $\begin{array}{c}-0.041^{* * *} \\
(0.009)\end{array}$ & $\begin{array}{c}0.022 \\
(0.019)\end{array}$ & $\begin{array}{c}-0.008^{* *} \\
(0.004)\end{array}$ & $\begin{array}{c}-0.046^{* * *} \\
(0.015)\end{array}$ & $\begin{array}{c}0.033 \\
(0.022)\end{array}$ \\
\hline Obs. & 671,499 & 671,499 & 671,499 & 407,362 & 407,362 & 407,362 \\
\hline
\end{tabular}

Notes: These coefficients are generated replicating the results of Tables 3 and 4 using in Panels A, C, E, $\mathrm{G}, \mathrm{H}, \mathrm{J}, \mathrm{l}$ and $\mathrm{N}$ weekday fixed effects, rather than controlling for working days, including more refined controls for weather conditions in Panels B, C, F, G, I, J, M and N, implementing a two-way clustering in Panels D-G and K-N and combining weekday fixed effects, weather controls and two-way clustering in Panels G and N. The sample without the large cities is defined by dropping the observations for the provinces of Madrid, Barcelona, Valencia, and Seville. In each specification, we control for quarteryear and province fixed effects and provincial linear trends. Robust standard errors clustered at the province-quarter-year level in parentheses. Significance at the $10 \%$ level is represented by *, at the $5 \%$ level by ${ }^{* *}$, and at the $1 \%$ level by ***. 


\section{Appendix A: Additional Figures and Tables}

This Appendix provides additional tables and figures, which are also discussed in the paper. In particular, we present the following:

- Accident rate trends with treatment based on the median (Figure A1);

- Variable description (Table A1);

- Accident rate channels (Table A2);

- Accident severity - spatial panel fixed effects (Table A3);

- Continuous treatment: Accident rates at the provincial-quarter level (Table A4);

- Continuous treatment: Characteristics of the people involved (Table A5);

- Continuous treatment: Vehicles and accident context (Table A6);

- Continuous treatment: Characteristics of the people involved without the large cities (Table A7);

- Continuous treatment: Vehicles and accident context without the large cities (Table A8) 
Figure A.1: Accidents rate trends with treatment based on the median

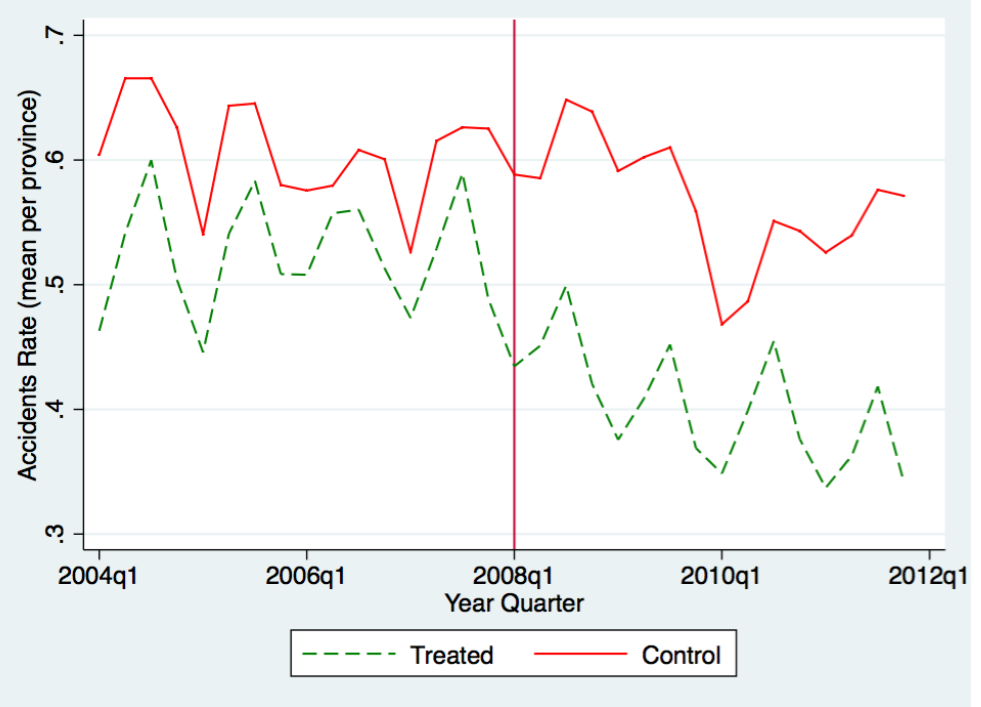

Notes: In this figure, treated and control are classified according to the median of employment in the construction sector distribution. 
Table A.1: Variables

\begin{tabular}{|c|c|c|}
\hline Variable & Definition & Level \\
\hline Death & Dummy $=1$ if the person involved died & Individual\&Vehicles \\
\hline Severe Injury & $\begin{array}{l}\text { Dummy }=1 \text { if the person involved reported a } \\
\text { severe injury }\end{array}$ & Individual\&Vehicles \\
\hline Minor Injury & $\begin{array}{l}\text { Dummy }=1 \text { if the person involved reported a } \\
\text { minor injury }\end{array}$ & Individual\&Vehicles \\
\hline Age & Continuous & Individual\&Vehicles \\
\hline Alcohol\&Drugs & $\begin{array}{l}\text { Dummy }=1 \text { if the person involved was under } \\
\text { the effect of drug or alcohol }\end{array}$ & Individual\&Vehicles \\
\hline Female & Dummy $=1$ if the person involved was a female & Individual\&Vehicles \\
\hline Less Driving Experience & $\begin{array}{l}\text { Dummy }=1 \text { if the driving license was issued } 5 \\
\text { or less years before the accident }\end{array}$ & Individual\&Vehicles \\
\hline Maintenance Problems & $\begin{array}{l}\text { Dummy }=1 \text { if the vehicle had any tire, break, light } \\
\text { and related problems }\end{array}$ & Individual\&Vehicles \\
\hline More Driving Experience & $\begin{array}{l}\text { Dummy }=1 \text { if the driving license was issued } 10 \\
\text { or more years before the accident }\end{array}$ & Individual\&Vehicles \\
\hline New Vehicles & $\begin{array}{l}\text { Dummy }=1 \text { if the vehicle was registered } 2 \\
\text { years or less before the accident }\end{array}$ & Individual\&Vehicles \\
\hline Passenger & Dummy $=1$ if the person involved/injured was a passenger & Individual\&Vehicles \\
\hline Precautions & $\begin{array}{l}\text { Dummy }=1 \text { if any precaution measure was } \\
\text { adopted }(e . g ., \text { seatbelt, helmet, child restraint system })\end{array}$ & Individual\&Vehicles \\
\hline Spanish & Dummy $=1$ if the person involved was Spanish & Individual\&Vehicles \\
\hline Stressed\&tired & $\begin{array}{l}\text { Dummy }=1 \text { if the person involved reported } \\
\text { she was stressed out or tired }\end{array}$ & Individual\&Vehicles \\
\hline Short trip & $\begin{array}{l}\text { Dummy }=1 \text { if the reason for travel was } \\
\text { a short trip }\end{array}$ & Individual\&Vehicles \\
\hline
\end{tabular}

Notes: The data were released by the Spanish General Directorate of Traffic. 
Table A.1: Variables (Cont'd)

\begin{tabular}{|c|c|c|}
\hline Variable & Definition & Level \\
\hline Dry\&Clean Street & $\begin{array}{l}\text { Dummy }=1 \text { if the accident took place on a clean and } \\
\text { dry street }\end{array}$ & Accident \\
\hline Good Weather & $\begin{array}{l}\text { Dummy }=1 \text { if the accident took place in good } \\
\text { weather conditions }\end{array}$ & Accident \\
\hline Sunny & Dummy $=1$ if the accident took place on a sunny day & Accident \\
\hline Foggy & Dummy $=1$ if the accident took place on a foggy day & Accident \\
\hline Rainy & Dummy $=1$ if the accident took place on a rainy day & Accident \\
\hline No State Street & $\begin{array}{l}\text { Dummy }=1 \text { if the accident took place on a street } \\
\text { what is not managed by the central state administration }\end{array}$ & Accident \\
\hline Rush Hours & $\begin{array}{l}\text { Dummy }=1 \text { if the accident took place from } 8 \text { to } 9 \mathrm{am} \text {, } \\
\text { from } 12 \text { to } 2 \mathrm{pm} \text {, and from } 6 \text { to } 9 \mathrm{pm}\end{array}$ & Accident \\
\hline Vehicles & Number of Vehicles involved in the accident & Accident \\
\hline Working Days & Dummy $=1$ if the accident took place on a workday & Accident \\
\hline Weekend & Dummy $=1$ if the accident took place during the weekend & Accident \\
\hline N. of People in the Vehicle & Number of people in the vehicles involved in the accident & Accident \\
\hline Investment in Infrastructure & $\begin{array}{l}\text { Investment in infrastructure by resident population } \\
\text { in } 10,000 \mathrm{~s} \text { in } 2007\end{array}$ & Province \\
\hline $\begin{array}{l}\text { Number of Registered } \\
\text { Vehicles }\end{array}$ & $\begin{array}{l}\text { The number of register vehicles per 1,000 inhabitants } \\
\text { in } 2007\end{array}$ & Province \\
\hline Population Density & Population density in 2007 & Province \\
\hline
\end{tabular}

Notes: The data were released by the Spanish General Directorate of Traffic. 


\section{Table A.2: Accident rate channels}

\begin{tabular}{|c|c|c|c|}
\hline & Investment in Infrastructure & Population Density & Number of Registered Vehicles \\
\hline Crisis & $\begin{array}{c}\text { Less Investment } \\
-0.058^{*} \\
(0.032)\end{array}$ & $\begin{array}{c}\text { Low Density } \\
-0.091^{* * *} \\
(0.031)\end{array}$ & $\begin{array}{c}\text { Less Registered Vehicles } \\
-0.078^{* *} \\
(0.038)\end{array}$ \\
\hline Crisis & $\begin{array}{c}\text { More Investment } \\
-0.062^{*} \\
(0.032)\end{array}$ & $\begin{array}{c}\text { High Density } \\
-0.029 \\
(0.031)\end{array}$ & $\begin{array}{c}\text { More Registered Vehicles } \\
-0.053^{*} \\
(0.029)\end{array}$ \\
\hline Difference & $\begin{array}{c}0.030 \\
(0.039)\end{array}$ & $\begin{array}{c}0.062^{*} \\
(0.034)\end{array}$ & $\begin{array}{c}0.024 \\
(0.039)\end{array}$ \\
\hline
\end{tabular}

Notes: Robust standard errors clustered at the province-quarter level in parentheses. Significance at the $10 \%$ level is represented by ${ }^{*}$, at the $5 \%$ level by ${ }^{* *}$, and at the $1 \%$ level by $* * *$.

Table A.3: Accident severity - spatial panel fixed effects

\begin{tabular}{lccc}
\hline \hline & Death & Severe Injury & Minor Injury \\
\hline \hline \multirow{2}{*}{ Crisis } & $-0.003^{*}$ & $-0.013^{* *}$ & $0.014^{*}$ \\
& $(0.002)$ & $(0.006)$ & $(0.008)$ \\
& & & \\
$\lambda$ & $-0.243^{* * *}$ & $-0.134^{* *}$ & -0.011 \\
$\rho$ & $-0.217^{* *}$ & -0.027 & 0.105 \\
& & & \\
Obs. & 1,600 & 1,600 & 1,600 \\
\hline \hline
\end{tabular}

Notes: $\lambda$ is the spatial autocorrelation parameter, and $\rho$ is the spatial autoregressive coefficient. Robust standard errors clustered at the provincial-quarter level in parentheses. Significance at the $10 \%$ level is represented by ${ }^{*}$, at the $5 \%$ level by $* *$, and at the $1 \%$ level by $* * *$. 
Table A.4: Continuous treatment: accident rates at the provincial-quarter level

\begin{tabular}{lcc}
\hline \hline & All & Working days \\
\hline \hline DD & & \\
Crisis & $-0.012^{* *}$ & -0.007 \\
& $(0.005)$ & $(0.005)$ \\
& & \\
\hline Spatial panel fixed effects \\
Crisis & $-0.012^{* * *}$ & -0.007 \\
& $(0.004)$ & $(0.004)$ \\
$\lambda$ & 0.0 .054 & 0.135 \\
$\rho$ & $0.170^{*}$ & $0.213^{* * *}$ \\
Obs. & 1,600 & 1,600 \\
Mean & 0.482 & 0.253 \\
\hline \hline
\end{tabular}

Notes: Crisis is the interaction between the provincial level employment rate in the construction sector and the dummy for the period after the first quarter of 2008. Robust standard errors clustered at the provincial level in parentheses. Significance at the $10 \%$ level is represented by $*$, at the $5 \%$ level by ${ }^{* *}$, and at the $1 \%$ level by $* * *$. 
Table A.5: Continuous treatment: characteristics of the people involved

\begin{tabular}{|c|c|c|c|c|}
\hline \multicolumn{5}{|c|}{ Panel A: Age } \\
\hline & Age & Age less 30 & Age 30 to 60 & Older than 60 \\
\hline Crisis & $\begin{array}{c}0.068^{* * *} \\
(0.026)\end{array}$ & $\begin{array}{c}-0.002^{* * *} \\
(0.001)\end{array}$ & $\begin{array}{c}-0.003^{* * *} \\
(0.001)\end{array}$ & $\begin{array}{c}0.005^{* * *} \\
(0.001)\end{array}$ \\
\hline Obs. & $1,614,270$ & $1,614,270$ & $1,614,270$ & $1,614,270$ \\
\hline \multicolumn{5}{|c|}{ Panel B: Conditions } \\
\hline & Alcohol & Stressed\&Tired & Female & Spanish \\
\hline Crisis & $\begin{array}{c}0.001^{* * *} \\
(0.000)\end{array}$ & $\begin{array}{c}0.000 \\
(0.000)\end{array}$ & $\begin{array}{c}-0.000 \\
(0.000)\end{array}$ & $\begin{array}{c}0.001 \\
(0.003)\end{array}$ \\
\hline Obs. & $1,752,029$ & $1,771,809$ & $1,733,700$ & $1,679,625$ \\
\hline
\end{tabular}

Panel C: Driving behaviour\& experience

Precautions Less Driving Experience More Driving Experience

\begin{tabular}{cccc} 
Crisis & 0.001 & $-0.005^{* * *}$ & $0.007^{* * *}$ \\
& $(0.002)$ & $(0.001)$ & $(0.002)$ \\
Obs. & $1,184,028$ & $1,257,838$ & $1,257,838$ \\
\hline
\end{tabular}

Panel D: Age of the drivers

$\begin{array}{lll}\text { Age } & \text { Age less } 30 & \text { Age } 30 \text { to } 60 \quad \text { Older than } 60\end{array}$

\begin{tabular}{lcccc} 
Crisis & $\begin{array}{c}0.081^{* * *} \\
(0.023)\end{array}$ & $\begin{array}{c}-0.002^{* * *} \\
(0.001)\end{array}$ & $\begin{array}{c}-0.003^{* *} \\
(0.001)\end{array}$ & $\begin{array}{c}0.005^{* * *} \\
(0.001)\end{array}$ \\
Obs. & $1,184,028$ & $1,184,028$ & $1,184,028$ & $1,184,028$ \\
\hline \multirow{2}{*}{ Panel E: Conditions of the driver } & Stressed\&Tired & & \\
& Alcohol & Female & Spanish \\
Crisis & $0.001^{* * *}$ & 0.000 & 0.000 & 0.002 \\
& $(0.000)$ & $(0.000)$ & $(0.000)$ & $(0.003)$ \\
Obs. & $1,257,838$ & $1,257,838$ & $1,247,127$ & $1,257,838$ \\
\hline
\end{tabular}

Panel F: Driving behaviour \& experience of the driver

Precautions Less Driving Experience More Driving Experience

\begin{tabular}{cccc} 
Crisis & 0.002 & $-0.007^{* * *}$ & $0.009^{* * *}$ \\
& $(0.002)$ & $(0.002)$ & $(0.002)$ \\
Obs. & $1,257,838$ & $1,257,838$ & $1,257,838$ \\
\hline
\end{tabular}

Notes: Robust standard errors clustered at the province-quarter-year-level in parentheses. In each specification, we control for quarter-year and province fixed effects and provincial linear trends. Significance at the $10 \%$ level is represented by $*$, at the $5 \%$ level by ${ }^{* *}$, and at the $1 \%$ level by ***. 


\section{Table A.6: Continuous treatment: vehicles and accident context}

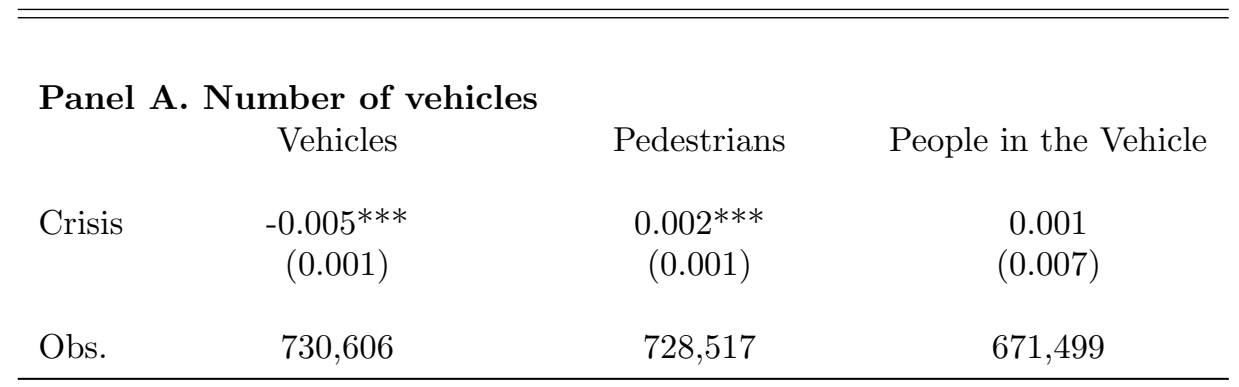

Panel B: Conditions Maintenance Problems New Vehicles

Crisis $\quad-0.000 \quad-0.001$

$(0.000) \quad(0.001)$

$\begin{array}{lll}\text { Obs. } & 1,771,809 & 1,771,809\end{array}$

Panel C: Timing and type of accident

Rush Hours Working Days Weekend

\begin{tabular}{lccc} 
Crisis & $-0.001^{* *}$ & -0.000 & 0.001 \\
& $(0.000)$ & $(0.003)$ & $(0.001)$ \\
Obs. & 730,606 & 730,606 & 730,606 \\
\hline
\end{tabular}

Panel D: Weather and street status

Good Weather Dry \& Clean Street

\begin{tabular}{lcc} 
Crisis & 0.004 & -0.001 \\
& $(0.003)$ & $(0.001)$ \\
Obs. & 730,606 & 730,606 \\
\hline
\end{tabular}

Panel E: Motive of the trip Short Trip

No State Street

Crisis

$$
0.009^{*} \quad 0.005^{* * *}
$$

Obs.

$1,679,625$

730,606

Notes: Robust standard errors clustered at the province-quarter level in parentheses. In each specification, we control for quarter-year and province fixed effects and provincial linear trends. Significance at the $10 \%$ level is represented by ${ }^{*}$, at the $5 \%$ level by ${ }^{* *}$, and at the $1 \%$ level by $* * *$. 
Table A.7: Continuous treatment: characteristics of the people involved (No large cities)

\begin{tabular}{|c|c|c|c|c|}
\hline \multicolumn{5}{|c|}{ Panel A: Age } \\
\hline & Age & Age less 30 & Age 30 to 60 & Older than 60 \\
\hline Crisis & $\begin{array}{c}0.094^{* * *} \\
(0.029)\end{array}$ & $\begin{array}{c}-0.003^{* * *} \\
(0.001)\end{array}$ & $\begin{array}{c}-0.002 \\
(0.001)\end{array}$ & $\begin{array}{c}0.006^{* *} \\
(0.002)\end{array}$ \\
\hline Obs. & 911,762 & 911,762 & 911,762 & 911,762 \\
\hline \multicolumn{5}{|c|}{ Panel B: Conditions } \\
\hline & Alcohol & Stressed\&Tired & Female & Spanish \\
\hline Crisis & $\begin{array}{c}0.000^{* * *} \\
(0.000)\end{array}$ & $\begin{array}{l}-0.000 \\
(0.000)\end{array}$ & $\begin{array}{c}0.000 \\
(0.001)\end{array}$ & $\begin{array}{l}-0.004 \\
(0.004)\end{array}$ \\
\hline Obs. & 977,393 & 987,656 & 942,520 & 965,543 \\
\hline
\end{tabular}

Panel C: Driving behavior \& experience

Precautions Less Driving Experience More Driving Experience

\begin{tabular}{lccc} 
Crisis & 0.001 & $-0.007^{* * *}$ & $0.009^{* * *}$ \\
& $(0.002)$ & $(0.001)$ & $(0.002)$ \\
Obs. & 987,656 & 987,656 & 987,656 \\
\hline
\end{tabular}

Panel D: Age of the drivers

Age Age less $30 \quad$ Age 30 to $60 \quad$ Older than 60

\begin{tabular}{ccccc} 
Crisis & $0.126^{* * *}$ & $-0.004^{* * *}$ & -0.002 & $0.006^{* *}$ \\
& $(0.022)$ & $(0.001)$ & $(0.002)$ & $(0.002)$ \\
Obs. & 649,143 & 649,143 & 649,143 & 649,143 \\
\hline
\end{tabular}

Panel E: Conditions of the driver Alcohol Stressed\&Tired $\quad$ Female Spanish

\begin{tabular}{ccccc} 
Crisis & $0.001^{* * *}$ & 0.000 & 0.000 & -0.004 \\
& $(0.000)$ & $(0.000)$ & $(0.000)$ & $(0.004)$ \\
Obs. & 678,301 & 678,301 & 671,855 & 678,301 \\
\hline
\end{tabular}

Panel F: Driving behavior \& experience of the driver

Precautions Less Driving Experience More Driving Experience

\begin{tabular}{cccc} 
Crisis & -0.000 & $-0.010^{* * *}$ & $0.013^{* * *}$ \\
& $(0.002)$ & $(0.002)$ & $(0.002)$ \\
& & & \\
Obs. & 678,301 & 678,301 & 678,301 \\
\hline \hline
\end{tabular}

Notes: The sample is defined by dropping the observations for the provinces of Madrid, Barcelona, Valencia, and Seville. In each specification, we control for quarter-year and province fixed effects and provincial linear trends. Robust standard errors clustered at the province-quarter-year level in parentheses. Significance at the $10 \%$ level is represented by $*$, at the $5 \%$ level by **, and at the $1 \%$ level by ***. 
Table A.8: Continuous treatment: vehicles and accident context (No large cities)

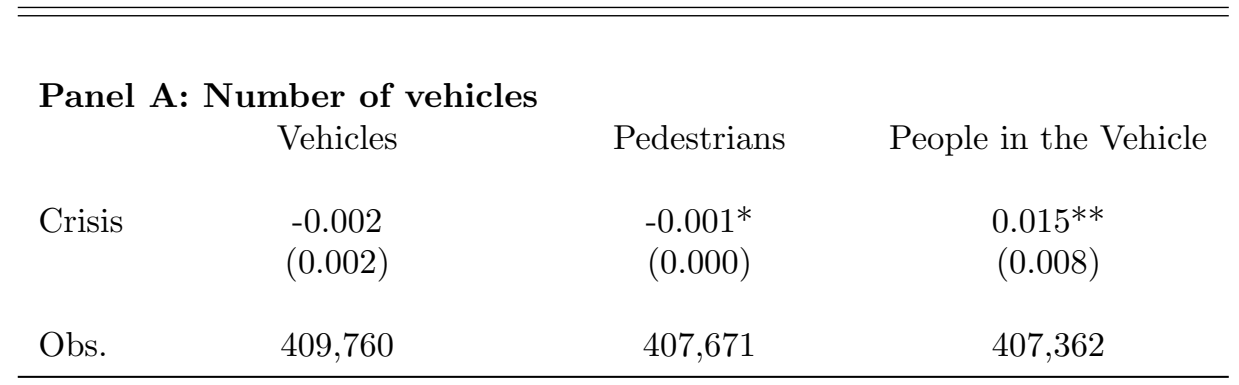

Panel B: Conditions Maintenance Problems New Vehicles

Crisis $\quad-0.000^{*} \quad 0.000$

$(0.000) \quad(0.001)$

$\begin{array}{ll}\text { Obs. } & 987,656\end{array}$

Panel C: Timing and type of accident Rush Hours Working Days Weekend

\begin{tabular}{lccc} 
Crisis & -0.000 & 0.002 & 0.000 \\
& $(0.001)$ & $(0.002)$ & $(0.001)$ \\
Obs. & 409,760 & 409,760 & 409,760 \\
\hline
\end{tabular}

Panel D: Weather and street status

Good Weather Dry \& Clean Street

\begin{tabular}{lcc} 
Crisis & $-0.004^{* *}$ & $-0.004^{* * *}$ \\
& $(0.002)$ & $(0.001)$ \\
& & \\
Obs. & 409,760 & 409,760 \\
\hline
\end{tabular}

Panel E: Motive of the trip Short Trip No State Street

Crisis $\quad-0.008^{*} \quad 0.001$

$(0.004) \quad(0.001)$

Obs. $\quad 942,520 \quad 409,760$

Notes: The sample is defined by dropping the observations for the provinces of Madrid, Barcelona, Valencia, and Seville. In each specification, we control for quarter-year and province fixed effects and provincial linear trends. Robust standard errors clustered at the provincequarter level in parentheses. Significance at the $10 \%$ level is represented by ${ }^{*}$, at the $5 \%$ level by $* *$, and at the $1 \%$ level by $* * *$. 